U.S. GEOLOGICAL SURVEY CIRCULAR 1037

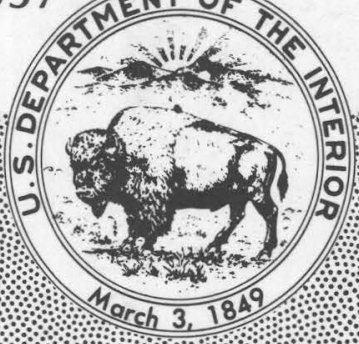

\title{
Metalliferous Black Shales and Related Ore Deposits- Program and Abstracts
}



Metalliferous Black Shales and Related Ore DepositsProgram and Abstracts 


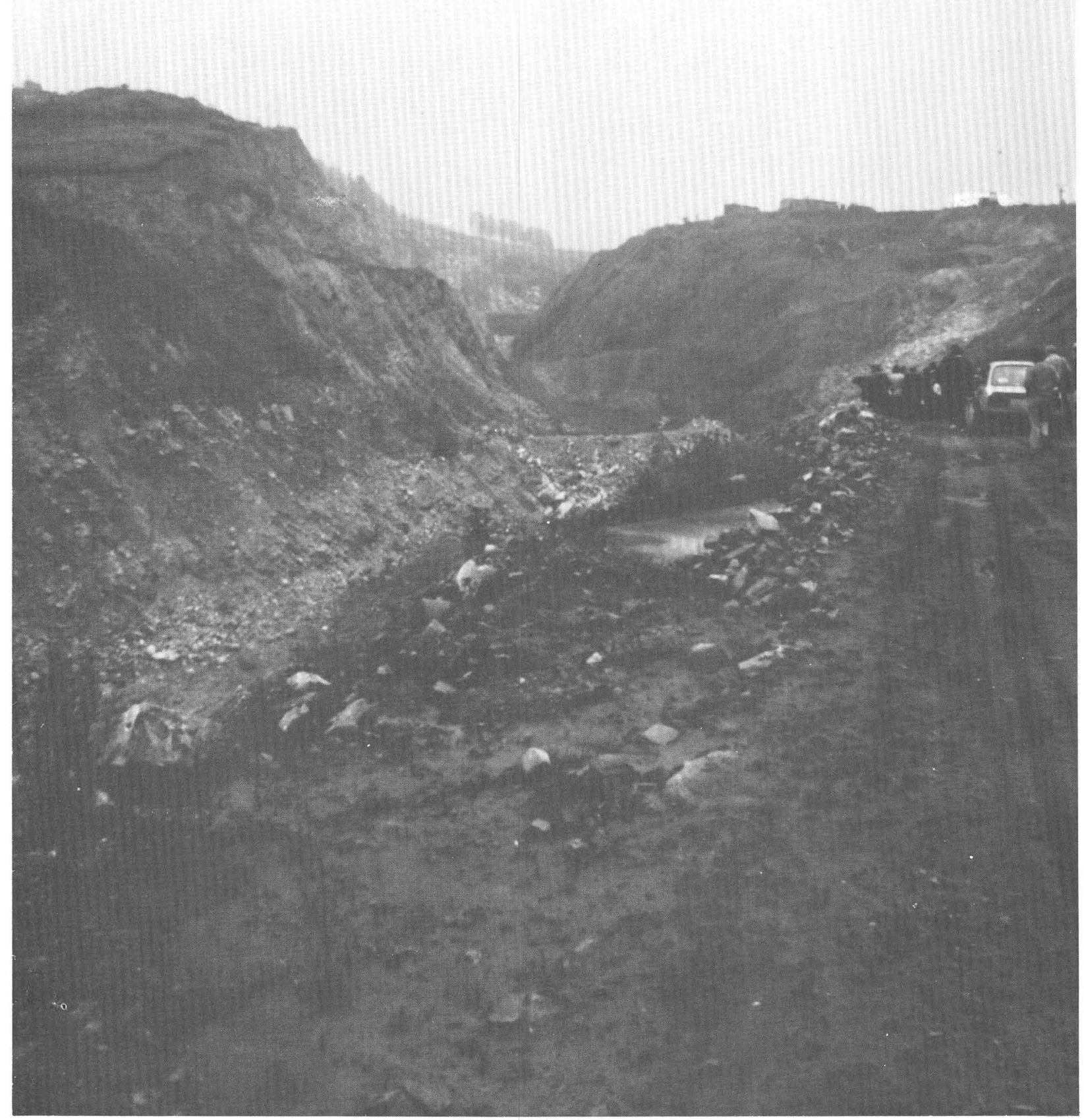

Konstantin graphite mine, Velké Vrbno, Czechoslovakia. Graphite is hosted by pre-Devonian metamorphosed black shales and carbonates. Photograph by Richard I. Grauch, 1987. 


\section{Metalliferous Black Shales and Related Ore Deposits- Program and Abstracts}

Edited by RICHARD I. GRAUCH and JOEL S. LEVENTHAL

1988 Meeting of the

United States Working Group of

International Geological Correlation Program Project 254

U.S. GEOLOGICAL SURVEY CIRCULAR 1037 


\section{DEPARTMENT OF THE INTERIOR \\ MANUEL LUJAN, JR., Secretary}

U.S. GEOLOGICAL SURVEY

Dallas L. Peck, Director

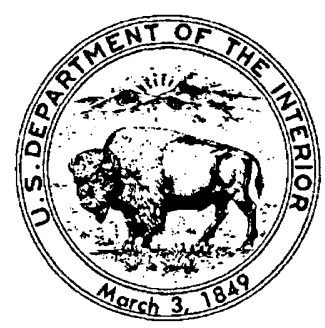

Organizing committee for the 1988 meeting of the International Geological Correlation Program:

Project 254 United States Working Group:

Richard I. Grauch, Chairman

Joel S. Leventhal

Library of Congress Cataloging-in-Publication Data

Metalliferous black shales and related ore deposits-program and abstracts / edited by Richard I. Grauch and Joel

S. Leventhal.

p. cm. - (U.S. Geological Survey circular ; 1037)

Includes bibliographical references.

Supt. of Docs. no.: I 19.4/2:1037

1. Shale-Congresses. 2. Ore deposits-Congresses. I. Grauch, Richard I. II. Leventhal, Joel S.

III. Geological Survey (U.S.) IV. Series.

TN948.S5M47 1990

$553.2^{\prime} 83-\mathrm{dc} 20$

$89-600243$

CIP

Any use of trade, product, industry, or firm names in this publication is for descriptive purposes only and does not imply endorsement by the U.S. Government

Free on application to the Books and Open-File Services Section,

U.S. Geological Survey, Federal Center, Box 25425, Denver, CO 80225 


\section{FOREWORD}

\section{Richard I. Grauch, Leader, United States Working Group, International Geological Correlation Program Project 254 Vice-Leader, International Geological Correlation Group Project 254}

The abstracts and extended abstracts of this circular are summaries of most of the papers presented at the October 29, 1988, meeting of the U.S. Working Group of the International Geological Correlation Program's Project 254, METALLIFEROUS BLACK SHALES AND RELATED ORE DEPOSITS.

The International Geological Correlation Program (IGCP) has two principal objectives. The "primary goal is to encourage and facilitate geological research on a global scale, and to foster international cooperation. Current research stresses the nature and timing of major geologic events, the distribution and genesis of mineral and energy resources, and geological hazards" (B.J. Skinner and C.L. Drake, 1987, An unacclaimed success story: Geotimes, v. 32, no. 4, p. 11). "A secondary objective of many IGCP projects is to improve the geological capability and knowledge in developing countries" (U.S. National Committee for International Geological Correlation Program, 1988, The International Geological Correlation Program, Newsletter 8, p. i). The IGCP is a joint functionary of the International Union of Geological Sciences (IUGS) and the United Nations Educational, Scientific, and Cultural Organization (UNESCO). It is guided by an advisory Scientific Committee and by a 15 -member board of scientists who are jointly appointed by IUGS and UNESCO. Most of the 90 participating nations have appointed National Committees to coordinate the activities of the various National Working Groups that are associated with individual IGCP projects.

IGCP Project 254 was initiated by Jan Pasava of the Geological Survey, Prague, Czechoslovakia. Its primary, very ambitious, goals are: (1) compile and correlate data regarding metalliferous black-shale formations and related ore deposits, (2) evaluate the role of depositional, diagenetic, volcanic, magmatic, metamorphic, and tectonic processes in the origin of metalliferous black shales and related ore deposits, (3) investigate the roles of organic matter and sulfide in mineralization processes, and (4) develop exploration criteria for ore deposits in black shale formations. 
The leadership of the project is:

$\begin{array}{ll}\text { Leader: } & \text { J. Pasava, Czechoslovakia } \\ \text { Vice-Leaders: } & \text { R.I. Grauch, U.S.A. } \\ \text { Secretary: } & \text { V.A. Buryak, U.S.S.R. } \\ \text { Treasurer: } & \text { Z. Guchardt, Denmark } \\ \text { Executive Board: } & \text { I.R. Plimer, Czechoslovakia } \\ & \text { I.R. Jonasson, Canadia } \\ & \text { B. Kribek, Czechoslovakia } \\ \text { M. Pulec, Czechoslovakia } \\ \text { K. Ruskeeniemi, Finland } \\ \text { M. Pagel, France } \\ \text { B. Stribrny, Federal Republic of Germany } \\ \text { H. Dill, Federal Republic of Germany } \\ \text { R.C. Mehrotra, India } \\ \text { F. El Salem, Jordan } \\ \text { A. Tijani, Morocco } \\ \text { M. Banas, Poland } \\ \text { L. Moshen, Tunisia } \\ \text { V. Petrov, U.S.S.R. } \\ \text { S. Rodriguez, Venezuela } \\ \text { N. Shaffer, U.S.A. } \\ \text { Fan Delian, People's Republic of China }\end{array}$

At the international level the project is divided into eight working groups: (1) Au and $\mathrm{Ag}$ mineralizations, (2) Pt-group element and $\mathrm{Cr}$ mineralizations, (3) $\mathrm{U}, \mathrm{Mo}$, and $\mathrm{V}$ mineralizations, (4) $\mathrm{Pb}, \mathrm{Zn}, \mathrm{Gu}$, and barite mineralizations, (5) $\mathrm{Cu}$ mineralizations, (6) $\mathrm{Sn}, \mathrm{W}, \mathrm{Hg}$, and $\mathrm{Sb}$ mineralizations, (7) $\mathrm{Mn}$ and $\mathrm{Fe}$ mineralizations, and (8) international standards and correlation of analytical measurements. Also, most of the 20 participating nations have formed multidisciplinary national working groups that have their own leaders and are expected to meet annually. These national working groups are generally loosely structured, and the individual participants are probably more closely aligned with the topical international working groups described above.

The diverse interests of the approximately 55 members (listed near the back of this circular) of the United States working group are well represented by the wideranging research topics presented at this meeting. We are excited about this new forum for communication and the synergism gained through international, multidisciplinary contacts. In addition, we have the ability (funded through the U.S. National Committee for IGCP) to assist in defraying the travel expenses of members who attend international project meetings and student members who attend national meetings. The next meeting of the United States working group will be in St. Louis in October 1989. The meetings are open to all interested persons, and the working group welcomes new members.

We thank the U.S. Geological Survey for cosponsoring this meeting and for publishing this circular. 


\section{International Meetings of International Geological Correlation Program Project 254}

October, 1987

July, 1988

July, 1989

1990

1991
Jesenik, Czechoslovakia; inaugural meeting and field trip.

Beijing, China. First international working session in conjunction with the International Association of Sedimentologists International Symposium on Sedimentology Related to Ore Deposits; field trips.

Washington, D.C., U.S.A. Second international working session in conjunction with the International Geological Congress, Symposium C25; field trip.

Ottawa, Canada. Third international working session in conjunction with the International Association on the Genesis of Ore Deposits Symposium.

Location to be determined. Closing session of Project 254. 


\title{
1988 MEETING OF THE UNITED STATES WORKING GROUP OF THE INTERNATIONAL GEOLOGICAL CORRELATION PROGRAM PROJECT 254, METALLIFEROUS BLACK SHALES AND RELATED ORE DEPOSITS
}

\author{
PROGRAM OF LECTURES AND DISCUSSIONS \\ Denver, Colorado, October 29, 1988
}

8:30 a.m

9:00

$9: 20$

9:30

9:50

10:00

10:15

$10: 35$

$10: 45$

11:05

11:15

$11: 45$

1:00 p.m.

$1: 20$

$1: 30$

$2: 00$

Introduction and brief business meeting Richard I. Grauch and Joel Leventhal, presiding

Elemental geochemistry of black shales. I. Low-calcic shales-Statistical comparison with other shales M.S. Quinby-Hunt, P. Wilde, C.J. Orth, and W.B.N. Berry

Discussion

Comparative geochemistry of metals and trace elements from the Cambrian Alum Shale of Sweden Joel S. Leventhal

Discussion

Coffee break

Elemental distributions in marine black shales Walter Dean

Discussion

A sulfur isotope study of the Leicester Pyrite Member (Middle Devonian) of western New York State-Preliminary results Timothy W. Lyons

Discussion

Ores in metal-rich shales of southern China Chen Nansheng and Raymond M. Coveney, Jr.

Discussion

Lunch break

Geochemical and mineralogic data indicating possible stratabound, bariferous base- and precious-metal deposits in the black slates of the Taconic Ranges, New York and Vermont, U.S.A. Kenneth $C$. Watts, Jr.

Discussion

Oxidation of organic matter in the mineralization process-Infrared spectroscopic analysis of kerogen from sediment-hosted ore deposits E.S. Ho, R.M. Kettler, and P.A. Meyers

Discussion

Some evolutionary pathways of metalliferous black shales and other fine-grained sediments-Uraniferous kerogens at Witwatersrand, South Africa; Elliot Lake, Canada; and Oklo, Gabon Bartholomew Nagy 


\section{PROGRAM OF LECTURES AND DISCUSSIONS (CONTINUED)}

2:50

3:00

$3: 45$

$4: 15$

$4: 45$

$6: 30$
Discussion

Effects of irradiation from uranium decay on the organic matter of the Alum shale, Sweden Jeremy Dahl, R. Hallberg, and I.R. Kaplan

Discussion

Sulfide-mineral textures in metal-rich units of the New Albany Shale, Indiana E.M. Ripley and N.R. Shaffer

Discussion

Coffee break

Informal comments and discussion:

Red Dog, Brooks Range, Alaska Jeanine Schmidt

Black-shale-hosted Mn deposits Dick Hammond

The global sedimentary geology program-what it is and what it does Mike Arthur

Final comments

Dinner and informal discussions at the Leventhal residence 


\title{
Metalliferous Black Shales and Related Ore Deposits- Program and Abstracts
}

\author{
Edited by Richard I. Grauch and Joel S. Leventhal
}

\section{Effects of Irradiation from Uranium Decay on the Organic Matter of the Alum Shale, Sweden}

By Jeremy Dahl, Rolf Hallberg, and I.R. Kaplan, Institute of Geophysics and Planetary Physics, University of California at Los Angeles, Los Angeles, CA 90024-1567

Our work suggests that organic matter in the Alum Shale units of Sweden has been affected postdepositionally by irradiation from uranium decay. The age (Cambrian and Lower Ordovician) and uranium concentration of the Alum Shale units indicate a radiation dosage on the order of $10^{9}$ rads for samples which typically contain $190 \mathrm{ppm}$ uranium. Effects include lowering of kerogen atomic $\mathrm{H} / \mathrm{C}$ ratios and possibly the raising of atomic $\mathrm{O} / \mathrm{C}$ and ${ }^{13} \mathrm{C} /{ }^{12} \mathrm{C}$ stable isotopic ratios. The amount of extractable bitumen/total organic carbon and bitumen saturated/aromatic hydrocarbon ratios are inversely proportional to uranium concentration and, therefore, the irradiation dosage.

Biomarkers, including steranes, hopanes, tricyclic terpenes, pristine, and phytane, are absent in extracts from samples with high uranium concentrations, although they may be abundant in extracts from samples with low uranium concentrations. $\mathrm{C}_{20}, \mathrm{C}_{21}, \mathrm{C}_{26}, \mathrm{C}_{27}$, and $\mathrm{C}_{28}$ triaromatic steroids are present in extracts from samples with low uranium concentrations, whereas only $\mathrm{C}_{20}$ and $\mathrm{C}_{21}$ are present in extracts from samples with high uranium concentrations. Parent/alkylated PAH (polyaromatic hydrocarbons) ratios are higher in extracts from samples with high uranium concentrations.

Mechanisms presumed responsible for the effects described above include irradiation-induced aromatization, polymerization, and scission. These processes are

Manuscript approved for publication on May 25, 1989. known to occur when organic matter is irradiated both in natural settings, such as uranium organic sedimentary occurrences, and in the laboratory.

\section{Oxidation of Organic Matter in the Mineralization Process-Infrared Spectroscopic Analysis of Kerogen from Sediment-Hosted Ore Deposits}

\author{
By E.S. Ho, R.M. Kettler, and P.A. Meyers, \\ Department of Geological Sciences, University \\ of Michigan, Ann Arbor, MI 48109-1063
}

The role of organic matter in the formation of ore deposits is the subject of research at several sedimenthosted ore deposits, including White Pine (Michigan), Alligator Ridge (Nevada), Pueblo Viejo (Dominican Republic), and east Tennessee. Indications of correlation between the character or abundance of organic matter and metal (for example, copper, gold, silver) ores at these sites imply that geochemical interactions have occurred between organic matter in rock and metal-bearing fluids. Although the precise nature of these interactions remains unclear, one possibility is that oxidation of organic material and concomitant reduction of constituents in the mineralizing solution caused deposition of metal ores. We used infrared spectroscopic analysis of kerogens to detect any significant oxidation of organic material in mineralized versus nonmineralized samples. The kerogen infrared spectra allow the quantitative identification of any oxygen-containing functional groups (such as carbonyl, hydroxyl, and ether) in the organic material that may indicate the extent of oxidation of the organic matter.

At the White Pine deposit, the Middle Proterozoic Nonesuch Formation of the Keweenawan Supergroup, a lacustrine shale and sandstone unit, hosts copper-silver 
sulfide deposits. Mississippi Valley type deposits in east Tennessee are lead-zinc sulfides in a paleokarst Devonian carbonate setting. At Alligator Ridge, Devonian and Mississippian Pilot Shale hosts gold, and at Pueblo Viejo, Lower Cretaceous organic-carbon-rich rocks host gold and silver oxide (and sulfide) ores. At these sites there is some correlation between ore deposition and alteration of the organic material. Extractable organic matter from mineralized and nonmineralized samples was examined by gas chromatography. Kerogen from the same samples, isolated by dissolution of the rock matrix, was studied by element and carbon-isotope analyses, as well as infrared spectroscopy.

Preliminary infrared analyses of kerogens show absorption bands that correspond to various oxygencontaining functional groups. Also, we found that kerogen samples from different sites have a unique or signature spectrum. With further refinement of our techniques, it should be possible to establish, through infrared spectra subtraction, any significant difference between the functional groups in kerogen samples from the ore zone and kerogen samples from outside the ore zone. Such information would help establish whether oxidation of organic material at these sites is significant in the mineralization process.

\section{Comparative Geochemistry of Metals and Trace Elements from the Cambrian Alum Shale of Sweden}

\author{
By Joel S. Leventhal, U.S. Geological Survey, \\ Denver Federal Center, Box 25046, MS 973, \\ Denver, CO 80225
}

The Cambrian Alum Shale of Sweden is a metalrich black shale. However, the metal distribution varies with stratigraphic unit, and larger amounts of certain metals are in a metamorphosed area.

In nonmetamorphosed parts of the shale, uranium, molybdenum, vanadium, nickel, cadmium, and lead are enriched relative to other black shales. The kolm zones of the Alum Shale that are rich in organic matter (50 percent organic carbon) are more enriched in uranium (0.5 percent), radiogenic lead ( $200 \mathrm{ppm})$, yttrium ( 800 ppm) and heavier rare-earth elements (such as ytterbium, $45 \mathrm{ppm}$ ), but are depleted in molybdenum, vanadium, and nickel. Normalizing to aluminum accounts for the major and rock-forming elements but not the above-mentioned metals and trace elements in the shale and kolm. In most black shales, increased metal or trace-element contents can be accounted for by analogous increases in organic matter, pyrite, or phosphate as hosts or sites. However, simple ratios of trace elements to these hosts do not account for the concentrations of metals and trace elements in unmetamorphosed Alum Shale or kolm. These concentrations may result from selective transport and concentration by organic matter in an unusual depositional environment.

In the metamorphosed area, the organic carbon contents of the rocks are not greatly different, but the vanadium (0.2 percent), nickel (500 ppm), zinc (500 ppm), cadmium (10 ppm), and barium (1,500 ppm) contents are much greater, and phosphorus $(1,100 \mathrm{ppm})$ is somewhat greater. Addition of metals from other sources rather than redistribution of metals probably accounts for the increased amounts of vanadium, nickel, and zinc in the metamorphosed and tectonically affected area. During tectonism, vanadium, nickel, zinc, and barium may have been mobilized from underlying igneous rocks by heated fluids, and vanadium may also have come from the overlying Dictyonema zone as the fluids recycled.

\section{A Sulfur Isotope Study of the Leicester Pyrite Member (Middle Devonian) of Western New York State- Preliminary Results}

\author{
By Timothy W. Lyons, Department of Geology \\ and Geophysics, Yale University, \\ New Haven, CT 06511
}

\section{Background}

The Leicester Pyrite Member of the Genesee Formation is exposed in discontinuous lenses for $120 \mathrm{~km}$ in an outcrop belt of Middle Devonian strata spanning western New York State. The Leicester extends from central Erie County to the Finger Lakes region. From eastern Erie County to its easternmost extent, the Leicester is at or very slightly above the disconformable base of the Geneseo Shale Member (Baird and Brett, 1986) of the Genesee. These members constitute the basal beds of the Genesee and occur along the Taghanic unconformity, a hiatus of regional significance. The Leicester pyrite lenses are typically several centimeters thick and, as described by Baird and Brett (1986), consist of pyritic grains with subsidiary bone, conodont, and quartz-pebble fractions. In general, the pyritic material consists of irregular, nodular, and tabular grains, and, to a lesser degree, fossil steinkerns and permineralized wood (Baird and Brett, 1986).

The investigation of Baird and Brett (1986) was a major step towards an improved understanding of the enigmatic Leicester Pyrite Member. They described the spatial and stratigraphic distribution and the overall character, and gave a detailed genetic model. They 
suggested that the grains of the Leicester Pyrite Member were reworked from the subjacent strata as a consequence of erosion in a low- to zero-oxygen environment (thus pyrite oxidation was minimal). They maintained that internal turbulence combined with episodes of storm-generated turbulence may have exhumed and concentrated preexisting pyritic grains from the underlying sediment. Matrix winnowing and concomitant pyrite lag formation associated with a rising sea level were thought to be indicated by the diachronous nature of the Leicester, as well as the juxtaposition of the black-shale environment of the Geneseo and the underlying submarine erosional discontinuity.

\section{Present Study}

This study of the Leicester Pyrite Member has three goals: (1) to test the detrital pyrite model of Baird and Brett (1986) by geochemical means, (2) to increase understanding of the complex paragenesis represented by the Leicester Pyrite Member, and (3) to provide additional data to help understand pyritization phenomena in fine-grained, siliciclastic-dominated sediments. To date, the investigation has focused on one locality, the Fall Brook exposure near the town of Geneseo in the Genesee Valley of New York. Here, a Leicester lens averaging 3 to $5 \mathrm{~cm}$ thick is overlain by a well-laminated, fossil-free euxinic facies of the Geneseo Shale Member and is underlain by a gray, bioturbated, probably dysaerobic shale of the Windom Shale Member of the Moscow Formation (Hamilton Group). Preliminary results indicate that the Geneseo has a strong associated petroliferous odor, has organic and inorganic carbon contents of 2.88 and 3.00 percent, respectively, and has a total sulfur content of about 0.7 percent. Analyses of the Windom Shale Member revealed a $\mathrm{C}_{\text {organic }}$ concentration of 0.32 percent and a $\mathrm{C}_{\text {inorganic }}$ concentration of 4.57 percent. The total sulfur in the Windom measured about 1.0 percent, and lithologies near the Leicester were found to be relatively deficient in megafaunal elements. These data are from one sample from each of the adjacent shales.

The Leicester at Fall Brook is dominated by tubular (perhaps pyritized burrows) and nodular pyritic grains typically ranging from much less than 1 to $2 \mathrm{~cm}$ in size, and significantly lesser amounts of pyritic fossil debris. Associated with the pyritic materials are phosphatic bioclasts and minor quantities of glauconite, both of which are also assumed to have been concentrated during the lagforming process. Shale rip-up clasts were also observed, implying a notable degree of compactional sediment cohesiveness at the time of erosion. The intergrain areas include an abundant finer grained pyrite component which, as revealed by scanning-electron and reflected-light microscopy, contains framboids and numerous polyframboidal aggregates. The major pore-filling constituents include both mud matrix and sparry calcite cement, as well as moderate amounts of pore- and grain-fracture-filling barite and sphalerite. There are multiple pyrite generations, including pyrite-filled grain fractures and pyrite encrustations (overgrowths) on the margins of pyritic grains. Microscope observations of textural evidence (grain-contact relationships) strongly suggest that the majority of the overgrowth pyrite predates deposition of the Leicester. Additionally, many of the Leicester grains contain a relatively large percentage of included mud matrix.

Isotopically, the sulfur in the Leicester and the adjacent shales presents an intriguing picture. Sulfur from five samples of the overlying Geneseo Shale Member, extracted by means of chromium reduction (Canfield and others, 1986, a technique specific to reduced inorganic sulfur), has $\delta^{34} \mathrm{~S}$ values of $-6.47,-6.10$, $-3.48,-9.86$, and -3.28 per mil (all reported $\delta^{34} S$ values are expressed relative to Canyon Diablo troilite). Values of $\delta^{34} \mathrm{~S}$ determined for sulfur extracted from three samples of the underlying Windom Shale Member are $-4.22,-4.65$, and -2.24 per mil. These light, albeit only moderately light, bulk-shale isotopic values, relative to the Middle Devonian (late Givetian) seawater value of about 21 per mil of Claypool and others (1980), indicate sulfide precipitation as a product of bacterial sulfate reduction and accompanying isotopic fractionation. Megascopic pyritic features are not abundant in the Windom samples studied; however, one nodular grain collected proximal to the Windom-Leicester contact had a mean $\delta^{34} \mathrm{~S}$ value of +5.64 per mil. Interestingly but probably fortuitously, the bulk Leicester $\delta^{34} \mathrm{~S}$ value of +5.19 per mil $(\sigma=0.25)$ (homogenized Leicester sample, no precombustion extraction) is surprisingly close to the isotopic value of this Windom nodule.

Several microdrill subsamples were collected from individual Leicester pyritic grains. Where multiple pyrite generations were observed, attempts were made to include only one generation in a single microsample. The $\delta^{34} \mathrm{~S}$ values for these samples are summarized in table 1 . $\mathrm{SO}_{2}$ yields during sample combustion (assuming pure $\mathrm{FeS}_{2}$ ) that were lower than expected further substantiate the presence of nonpyrite inclusions within the pyrite grains. As is apparent from table 1, Leicester grains vary tremendously in sulfur isotopic composition, ranging from -17.77 to +43.35 per mil. Somewhat surprisingly, there is no appreciable systematic difference in isotopic character between the tubular and nodular grains; both have a wide spectrum of values.

Analyses of microsamples (samples L-6 and LP1d) taken from different places in the same grain revealed isotopically heavier sulfur towards the edge of the grains. None of the material in samples L-6 and 
Table 1. Summary of sulfur isotope data from microsamples of the Leicester Pyrite Member

\begin{tabular}{|c|c|c|}
\hline Sample No. & $\begin{array}{c}\text { Mean } \delta^{34} \mathrm{~S}(\mathrm{CDT}) \\
\text { (in per mil) }\end{array}$ & Description \\
\hline LP-1a ........... & +17.04 & Nodule. \\
\hline LP-1b ........... & +43.35 & Nodule. \\
\hline LP-1c............ & -17.77 & Nodule. \\
\hline \multicolumn{3}{|l|}{ LP-1d: } \\
\hline$d^{\prime} \ldots \ldots \ldots$ & +7.63 & Center of nodule. \\
\hline$d^{\prime \prime} \ldots \ldots \ldots$ & +9.58 & $\begin{array}{l}1 \text { mm edgeward } \\
\text { from LP-1d'. }\end{array}$ \\
\hline \multicolumn{3}{|l|}{ L-2: } \\
\hline a........... & +5.42 & $\begin{array}{l}\text { Center of somewhat } \\
\text { cylindrical grain, } \\
\text { possible pyritized } \\
\text { burrow. }\end{array}$ \\
\hline b ........... & -12.06 & $\begin{array}{l}\text { Slightly coarser } \\
\text { overgrowth on } \\
\text { grain margin. }\end{array}$ \\
\hline $\mathrm{L}-3 \ldots \ldots \ldots \ldots . .$. & +4.84 & Pyritized burrow. \\
\hline $\mathbf{L}-4 \ldots \ldots \ldots \ldots$ & +32.51 & Pyritized burrow. \\
\hline L-5 .............. & -13.24 & $\begin{array}{l}\text { Irregularly shaped } \\
\text { nodule. }\end{array}$ \\
\hline \multicolumn{3}{|l|}{ L-6: } \\
\hline a............ & +7.16 & $\begin{array}{l}\text { Edge of pyritized } \\
\text { burrow. }\end{array}$ \\
\hline b ............ & +.62 & $\begin{array}{l}\text { Interior of pyritized } \\
\text { burrow. }\end{array}$ \\
\hline
\end{tabular}

LP-1d was from well-developed, obvious overgrowths. This edgeward trend towards heavier sulfur probably reflects grain accretion in a closed or semiclosed system where pore-water sulfate and, as a consequence, sulfide became progressively heavier with continued sulfate reduction. In contrast, a selectively sampled pyrite overgrowth from sample L-2 (a possible pyritized burrow with what appears to be a well-developed overgrowth) yielded a $\delta^{34} S$ value 48 per mil lighter than the grain interior. One possible explanation involves interpreting the overgrowth as a pyritized organic or pellet-rich burrow lining. This phenomenon was widely observed by Baird and Brett (1986) in both the Windom and Leicester. Perhaps the isotopically light, pyritized lining was later filled with a heavier generation of pyrite as diagenesis progressed. The majority of the tubular grains observed during this study did, in fact, consist of solid pyrite cylinders rather than hollow tubes (although sphalerite-filled pyritic tubes were not uncommon).

The disparity between the bulk $\delta^{34} \mathrm{~S}$ values of the Windom, from which the grains of the Leicester are allegedly derived, and the microsample (mean $\delta^{34} \mathrm{~S}$ for all microsample analyses was $+7.09, \sigma$ was 17.87 ) and the bulk $\delta^{34} \mathrm{~S}$ values of the Leicester, is curious. The difference between the bulk Windom and the Leicester microsample data could be explained by insufficient data or, specifically, an isotopically light, finer grained pyrite fraction in the Leicester, which, because of its size, was unsampled. The bulk Leicester values, however, seem to refute this simple explanation. Three realistic explanations exist: (1) Due to size sorting, a fine-grained, isotopically light pyrite fraction in the Windom was not concentrated in the overlying Leicester lag. (2) The Leicester at Fall Brook was derived from Windom sediments quite different isotopically from those presently underlying the Leicester at this locality. Either the eroded Windom sediment in this area differed significantly or the pyritic material was transported to its final site of deposition (recall that the Windom at Fall Brook does not contain an abundance of pyritized grains). (3) The bulk Leicester $\delta^{34} \mathrm{~S}$ values reflect a major postdepositional diagenetic or hydrothermal overprint.

The complicated paragenesis of the Leicester certainly does not preclude hydrothermal episodes. Indeed, the late sphalerite mineralization indicates a hydrothermal signature. Nevertheless, the sulfur isotopic compositions of the Leicester tubular and nodular grains do not indicate the presence of later, high-temperature fluids. It is unreasonable to attribute $\delta^{34} S$ values of the magnitude and variability of those observed (in closely spaced samples) from the Leicester to hydrothermal processes (that is, later pyritization of an original carbonate lag). Instead, the data indicate a mixing of early diagenetic pyritic grains that formed at various depths of burial and had associated extents of sulfate reduction and degrees of system openness with respect to pore-water sulfate and sulfide. However, significant burial depths for Windom pyritization would necessitate erosion of great thicknesses of sediment in order to expose these grains for later accumulation in the Leicester.

Many questions still remain concerning the chemistry of the Leicester Pyrite Member. Perhaps additional analyses and a more regional perspective will shed further light on the geochemistry of the Leicester, including the still-mysterious paucity of associated carbonate allochems. The existing data, however, appear to concur with the observations of Baird and Brett (1986) and favor the detrital pyrite model proposed by them.

\section{References Cited}

Baird, G.C., and Brett, C.E., 1986, Erosion on an anaerobic seafloor-significance of reworked pyrite deposits from the Devonian of New York State: Palaeogeography, Palaeoclimatology, Palaeoecology, v. 57, p. 157-193.

Canfield, D.E., Raiswell, R., Westrich, J.T., Reaves, C.M., and Berner, R.A., 1986, The use of chromium reduction in the analysis of reduced inorganic sulfur in sediments and shales: Chemical Geology, v. 54, p. 149-155.

Claypool, G.E., Holser, W.T., Kaplan, I.R., Sakai, H., and Zak, I., 1980, The age curves of sulfur and oxygen isotopes in marine sulfate and their mutual interpretation: Chemical Geology, v. 28, p. 199-260. 


\section{Some Evolutionary Pathways of Metalliferous Black Shales and Other Fine-Grained Sediments-Uraniferous Kerogens at Witwatersrand, South Africa; Elliot Lake, Canada; and Oklo, Gabon}

\section{By Bartholomew Nagy, Laboratory of Organic Geochemistry, Department of Geosciences, University of Arizona, Tucson, AZ 85721}

The black, brownish-black, or dark-gray color of most shales, siltstones, and other fine-grained sedimentary rocks is mainly caused by finely admixed, sufficiently abundant kerogen. Metallic minerals also contribute to such coloration with, and in places without, kerogen. Elucidation of the nature and development of these rocks is an interdisciplinary endeavor and involves various factors that affected the geochemical system from the time of deposition (or occasionally prior to it) through geological history. When these rocks contain minerals of economic significance, the interdisciplinary stepwise evaluation of successive petrologic events is of more than usual significance.

Factors that affect the system range from biological and atmospheric considerations, to depositional, diagenetic, and(or) metamorphic environments, to mineralogy, stratigraphy, hydrothermal effects, to $\mathrm{P}, \mathrm{T}, \mathrm{pH}$, Eh, molarity relationships, and so forth, during petrologic history. Some of these factors are commonly considered, whereas others receive at best only cursory attention.

Three uraniferous kerogen deposits are briefly discussed to point out some probable events and constraints that occurred during their geologic histories. These histories may illustrate the diverse origins of metalliferous black shales and fine-grained rocks. In this report the term "kerogen" is used with a modifier where necessary to define its specific properties. In the modern study of basic organic geochemistry, this terminology is increasingly preferred to minimize potential misunderstandings. To illustrate this point, "thucholite" is an industrial term for kerogen containing thorium, uranium, carbon, hydrogen, and oxygen. But the latter three elements are present in all kerogens; thus, thorium- and uranium-bearing kerogen is still kerogen.

\section{The Auriferous, Uraniferous Witwatersrand Kerogens}

The Vaal Reef kerogen from the Witwatersrand, Africa, deposits has been studied in detail (the term "reef" refers to the gold- and uranium-bearing ore). The thin auriferous, uraniferous carbon layers are generally believed to be the remnants of extensive mats of ancient cyanobacteria (Pretorius, 1974), which developed in relatively quiescent areas on fine-grained sediments probably close to the seaward part of alluvial fans. The sediments, as well as most of the gold and uranium minerals, were derived from a crystalline upland and were first transported by proximal braided streams with shifting flow and bed-relief patterns (Smith and Minter, 1980). Farther to the seaward side of the alluvial fans and fan deltas, the energy of transport must have substantially subsided to prevent tearing and dispersion of the extensive cyanobacterial mats. At the time of the deposition of the Witwatersrand sediments $(2.8-3.0 \mathrm{Ga})$, no forms of life higher than prokaryotic microorganisms had evolved. Although microfossil-like objects have been found in the Vaal Reef kerogen, their syngenecity has not yet been established because of the technical difficulties of finding such objects embedded within the kerogen matrix, for example by transmission electron microscopy. Thus, evidence for prokaryotic mats is indirect. However, the lack of evidence for polymerization of gaseous or liquid hydrocarbons from sources such as hydrothermal effluences supports the microbiological origin. The cyanobacterial mats seem to have trapped and concentrated most of the uranium minerals, detrital gold, fine-grained quartz, as much as 28 percent clay, and a few other minerals occurring in minor abundances. Kerogen might be termed metalliferous, shale-rich organic matter. The mats also must have been affected by a rather reducing milieu; the contemporary atmosphere, as currently defined, was mainly $\mathrm{CO}_{2}$ and $\mathrm{N}_{2}$, with $\mathrm{H}_{2} \mathrm{O}$ and some CO. Scanning electron microscopy and electron microprobe analyses revealed small aggregates of clay minerals commonly a few micrometers in size, admixed in several kerogen layers (Zumberge and others, 1978). Euhedral gold crystals, showing no abrasion marks, and dendritic pyrite have also been identified in the kerogens, attesting to postdepositional crystallization. The kerogens did not seem to have been extensively mobilized by thermochemical reactions during their geologic history, although fractures in the adjacent fine-grained quartzite host rock have been filled in places by kerogen and seams of heavy minerals. The heavy minerals perhaps may be the result of hydrothermal episodes, as advanced diagenesis and mild metamorphism have been proposed at locales of the extensive Witwatersrand deposit. Molecular analyses of kerogen by combined vacuum pyrolysis, gas chromatography, and mass spectrometry revealed a coupled organic solid, releasing mainly alkylsubstituted aromatic hydrocarbons, and aliphatic hydrocarbons of low molecular weight, with some aromatic sulfur and aliphatic oxygen moieties (Zumberge and others, 1978). Compared to other uraniferous kerogens, the evolutionary pathways of the Witwatersrand deposits were relatively straightforward. 


\section{The Uraniferous, Auriferous Elliot Lake Kerogens}

The Elliot Lake, Canada, kerogens contain notably less gold than the Witwatersrand deposits, but some of them contain more uranium. They also indicate more complex evolutionary pathways. The major differences between the Elliot Lake and Witwatersrand kerogens are: there are at least two generations of kerogens, stratiform and more or less globular. The globular type in many places has morphologies of solidified liquid droplets and contains low uranium abundances. The stratiform kerogen is rich in detrital uraninite. Petrologic and geochemical observations and measurements suggest that the globular kerogen was derived from the stratiform kerogen considerably after deposition and burial.

The kerogens occur in the basal Matinenda Formation in the western part of the 2.25-2.45-Ga Huronian strata. The basal metasedimentary rocks were deposited by braided streams on alluvial fans; conglomerate, pebbly sandstone, arkosic sandstone, sandy limestone, and siltstone were deposited by fluvial action (Mossman and Harron, 1984). The uranium ore and associated kerogen were laid down in sedimentary cycles. Deposition started with coarse grains, mainly quartz, and gradually graded to minerals of increasingly finer grain size and terminated with the deposition of fine grains of uraninite in what are now the kerogen layers. This pattern had been considered a cycle of gradually decreasing energy of transport, leading to a period of quiescence when potential cyanobacterial mats could have developed (Ruzicka and Steacy, 1976). Subsequent depositional cycles commonly repeated this sequence. This pattern is the indirect, suggestive evidence for the presence of cyanobacterial mats at Elliot Lake. The kerogen layers are not as extensive here as they are in the Witwatersrand.

Molecular analyses of the Elliot Lake kerogens, as described above for the Witwatersrand kerogens, showed that the kerogen globules contained somewhat more abundant aliphatic moieties than the stratiform layers (Nagy and Mossman, in press). Reflectances of the globular matter were markedly lower, and its $\mathrm{H} / \mathrm{C}, \mathrm{O} / \mathrm{C}$ atomic ratios, determined as of this writing, were higher $(\mathrm{H} / \mathrm{C}$ about 0.8$)$ than those $(\mathrm{H} / \mathrm{C}$ about $0.4-0.6)$ of the stratiform kerogens (Willingham and others, 1985). In places, the layers were rimmed with kerogen showing markedly lower reflectances, as if this substance had exuded from the stratiform kerogen. Petrologic examination revealed that these rocks were subjected to hydrothermal episode(s). Therefore, thermochemical reactions, for example, some type of hydrous pyrolyses, could have mobilized part of the stratiform kerogen to the globular substance, the migration of which was subsequently arrested by diagenesis and mild meta- morphism. Mobilization should have occurred under strictly anoxic conditions to restrain dissolution of the detrital uraninite and thus preclude its incorporation into the globular kerogen. It has been suggested that few if any $n$-alkanes would survive in kerogens older than about 1.6-1.8 Ga. If so, the globular kerogen should have evolved approximately at this time, rather than at 2.45 $\mathrm{Ga}$, to account for its $n$-alkane constituents, setting a younger effective evolutionary age for the globular organic matter.

\section{The Uraniferous Oklo Kerogen}

The uraniferous kerogen at Oklo, Gabon, had probably the most unusual evolutionary pathway of the three areas described in this report. There are six natural nuclear reactor cores, $2 \mathrm{Ga}$ in age, where uranium chain fission processes occurred (Draganić and others, 1983). These cores are in sedimentary rocks in the Franceville basin, and their uranium content is $20-60$ percent. The sediments were probably buried several thousand meters deep but contained water which served as both coolant and moderator. The present ratio of ${ }^{235} \mathrm{U}$ to total $\mathrm{U}$ on Earth is 0.7 percent, but on the early Earth the abundance of ${ }^{235} \mathrm{U}$ was 40 times higher. The total energy liberated during the lifetime of the Oklo phenomenon was about $500 \times 10^{9}$ megajoules. Of course, the kerogen was heated, and globular kerogen here contains minute particles of dispersed pitchblende, suggesting unmixing from kerogen (Geffroy, 1975). These Oklo processes resulted in an extreme example of thermochemical and radiochemical reactions affecting kerogen and globular kerogen.

\section{References Cited}

Draganić, I.G., Draganić, Z.D., and Altiparmakov, D., 1983, Natural nuclear reactors and ionizing radiation in the Precambrian, in Nagy, Bartholomew, Weber, R., Guerrero, J.C., and Schidlowski, M., eds., Developments and interactions of the Precambrian atmosphere, lithosphere and biosphere: Amsterdam, Elsevier, Developments in Precambrian Geology, v. 7, p. 175-190.

Geffroy, J., 1975, Etude microscopique des minerals uraniferes d'Oklo, in Le phenomene d'Oklo: Vienna, International Atomic Energy Agency, p. 133-150.

Mossman, D.J., and Harron, G.A., 1984, Witwatersrand-type paleoplacer gold in the Huronian Supergroup of Ontario, Canada: Geoscience Canada, v. 11, p. 33-40.

Nagy, Bartholomew, and Mossman, D.J., 1988, Comparative molecular and elemental analyses of stratiform and dispersed-globular kerogens in lower Proterozoic metasediments, Elliot Lake, Canada-An investigation of kerogen paragenesis, in Schidlowski, M., ed., Early 
organic evolution-Implications for mineral and energy resources: New York, Springer Verlag, in press.

Pretorius, D.A., 1974, Gold in the Proterozoic sediments of South Africa-Systems, paradigms and models: University of Witwatersrand, Economic Geology Research Unit, Information Circular 87, 22 p.

Ruzicka, V., and Steacy, H.R., 1976, Some sedimentary features of conglomeratic uranium ore from Elliot Lake, Ontario, in Report of activities, part A: Geological Survey of Canada Paper 76-1A, p. 343-346.

Smith, N.D., and Minter, W.E.L., 1980, Sedimentological controls of gold and uranium in two Witwatersrand paleoplacers: Economic Geology, v. 75, p. 1-14.

Willingham, T.O., Nagy, Bartholomew, Nagy, L.A., Krinsley, D.H., and Mossman, D.J., 1985, Uranium-bearing stratiform organic matter in paleoplacers of the lower Huronian Supergroup, Elliot Lake-Blind River region, Canada: Canadian Journal of Earth Sciences, v. 22, p. 1930-1944.

Zumberge, J.E., Sigleo, A.C., and Nagy, Bartholomew, 1978, Molecular and elemental analyses of the carbonaceous matter in the gold and uranium bearing Vaal Reef carbon seams, Witwatersrand Sequence: Minerals Science and Engineering, v. 10, p. 223-246.

\section{Ores in Metal-Rich Shale of Southern China}

\section{By Chen Nansheng, Institute of Geochemistry, Academia Sinica Guiyang, Guizhou Province, People's Republic of China, and Raymond M. Coveney, Jr., Department of Geosciences, University of Missouri-Kansas City, Kansas City, MO 64110}

Ten provinces in southern China contain metalrich shales in Cambrian and other Paleozoic strata (Chen and others, 1982). Beds of special interest are gradational between coal and black shale, in the Lower Cambrian of Guizhou and western Hunan Provinces. These strata contain economically valuable amounts of molybdenum, nickel, vanadium, uranium, and other elements (Fan, 1983).

Since 1985 a stratiform nickel-molybdenum deposit near Songlin in Zunyi City, Guizhou (about 150 $\mathrm{km}$ by road from Guiyang, the provincial capital), has produced 1,000 tons of ore per year. The Songlin deposit, now developed by about 30 short adits, consists of a 2-m-thick horizon of nickel- and molybdenum-rich blackshale beds and a centrally located $5-15-\mathrm{cm}$ thick nickelmolybdenum sulfide lens. The ores are hosted by Lower Cambrian shales and generally contain about 2-4 percent molybdenum and about 2-4 percent nickel but may contain as much as 25 percent molybdenum. Assays of the Songlin shales also indicate the presence of as much as 1-2 percent zinc, $600-6,000 \mathrm{ppm}$ arsenic, $0.01-0.7$ ppm gold, $10-50 \mathrm{ppm}$ silver, about $180-1,900 \mathrm{ppm}$ selenium, $0.15-0.3 \mathrm{ppm}$ platinum (as well as other platinum-group elements), and 1,700 ppm copper (Fan and others, 1978; Fan and others, 1984; Institute of Geochemistry, Academia Sinica, 1981; Chen and others, 1982; Fan, 1983; Chen, in press). Available assays for black shales in southern China average about $18 \mathrm{ppb}$ iridium (Fan and others, 1984). Such large quantities of precious metals are unusual in black shale. For example, these amounts have not been found to date in molybdenum-rich (containing about 100-1,500 ppm Mo) shale that is widespread in the Pennsylvanian System of the American Midwest (for example, Coveney and others, 1987). Although production at the mine near Songlin is relatively small, the deposit is nevertheless noteworthy as it is the only mine in the world from which molybdenum is economically recovered from black shale-hosted ore. Ore from the sulfide layer that has been processed for molybdenum is stockpiled in anticipation of future recovery of nickel and precious metals.

The Songlin ore zone can be traced for about $6 \mathrm{~km}$ along the outcrop (it has not yet been drilled). Furthermore, similar nickel-molybdenum sulfide lenses occur at what seems to be the same stratigraphic horizon in western Hunan (for example, at the Doyong deposit, which is not presently mined). The widespread occurrence of nickel-molybdenum sulfide lenses in Lower Cambrian beds in Guizhou, Hunan, and elsewhere in southern China suggests the advisability of additional exploration efforts to delineate occurrences of shale-hosted nickel-molybdenum deposits.

Ores of the Songlin mine and related deposits in southern China can be spatially related to major regional basement faults. In some places, as in Hunan, host shales are closely associated with volcanic rocks of similar age. Textural features (Fan, 1983) and other factors imply that the metal enrichments in the shales of southern China formed syngenetically and during early diagenesis as a result of submarine hydrothermal springs that were active during sedimentation (Chen, in press).

\section{References Cited}

Chen Nansheng, in press, The Cambrian hydrothermal sedimentary molybdenum and nickel ore deposits in south China [abs.]: Abstracts for the International Association of Sedimentologists, International Symposium on Sedimentology Related to Mineral Deposits, Beijing.

Chen Nansheng, Yang Xiuzhen, Liu Dehan, Xiao Xuejun, Fan Delian, and Wang Lianfang, 1982, Lower Cambrian black argillaceous and arenaceous rock series in south China and its associated stratiform deposits [in Chinese]: Mineral Deposits, v. 1, no. 2, p. 39-51. 
Coveney, R.M., Jr., Leventhal, J.S., Glascock, M.D., and Hatch, J.R., 1987, Origins of metals and organic matter in Mecca Quarry shale and stratigraphically equivalent beds across the Midwest [United States]: Economic Geology, v. 82, p. 915-933.

Fan Delian, 1983, Polyelements in the Lower Cambrian black shale series in southern China, in Augstithis, S.S., ed., The significance of trace metals in solving petrogenetic problems and controversies: Athens, Greece, Theophrastus Publications, p. 447-474.

Fan Delian, Yang Ruiying, and Huang Zhongxiang, 1984, The Lower Cambrian black shale series and iridium anomaly in south China, in Su Zongwei, ed., Developments in geoscience; contributions to the 27th International Geological Congress: meeting, 1984, Moscow; Beijing, China, Science Press, p. 215-224.

Fan Delian, Yang Ziuzhen, Wang Lianfong, Chen Nansheng, and Xiao Xuejun, 1978, Trace elements in the Lower Cambrian stone coals and black series in some provinces of southern China [in Chinese], in Proceedings of the symposium on the comprehensive survey of stone coal resources in Southern China, v. 1: Beijing, China, Science Press, p. 26-40.

Institute of Geochemistry, Academia Sinica, 1981, Platinum bearing geological body in China [in Chinese], in Geochemistry of platinum group elements and minerals of the platinum group: Beijing, China, Science Press, p. 98-100.

\section{Elemental Geochemistry of Black Shales-Statistical Comparison of Low-Calcic Shales with Other Shales}

\author{
By M.S. Quinby-Hunt and Pat Wilde, Marine \\ Sciences Group, University of California, \\ Berkeley, CA 94720 \\ C.J. Orth, Isotope and Nuclear Chemistry \\ Division, Los Alamos National Laboratory, Los \\ Alamos, NM 87545
}

W.B.N. Berry, Marine Sciences Group, University of California, Berkeley, CA 94720

\section{Introduction}

Anoxic sedimentary environments of the past are recorded in black shales. Wedepohl (1968) noted that "average" shales reflect shallow-water sediments that accumulated under oxidizing conditions. Thus, the composition of so-called "average" shales does not represent past conditions where anoxic water and sediments were a significant component of the potential geologic record. Secondarily, as sediments resulting in black shales can be deposited under both oxic and anoxic conditions and in shallow to deep water, a black-shale composite better indicates oceanic conditions during the time of deposition than composites based primarily on shallow-water oxic conditions. Accordingly, we analyzed 287 samples of stratigraphically well documented $1 \mathrm{k}$ calcic Paleozoic and Mesozoic black shale, using neutrs: activation analysis, for: $\mathrm{Na}, \mathrm{Mg}, \mathrm{Al}, \mathrm{K}, \mathrm{Ca}, \mathrm{Sc}, \mathrm{Ti}, \mathrm{V}, \mathrm{Cr}$ $\mathrm{Mn}, \mathrm{Fe}, \mathrm{Co}, \mathrm{Zn}, \mathrm{Ga}, \mathrm{As}, \mathrm{Se}, \mathrm{Rb}, \mathrm{Sb}, \mathrm{Cs}, \mathrm{Ba}, \mathrm{Hf}, \mathrm{Ta}$, $\mathrm{Sl}$ and $\mathrm{U}$, and for the rare-earth elements $\mathrm{La}, \mathrm{Ce}, \mathrm{Nd}, \mathrm{Sm}$ $\mathrm{Eu}, \mathrm{Tb}, \mathrm{Dy}, \mathrm{Yb}$, and $\mathrm{Lu}$.

This study expands the compilation of North American black shales by Vine and Tourtelot (1970) by the addition of 16 elements, including the first compilation of the rare-earth-element series for black shales. In this report, our data are compared with the black-shale compilation (V\&T:BSC) of Vine and Tourtelot (1970) and with other general shale compilations such as Turekian and Wedepohl (1961) and Gromet and others (1984).

This study (called the Marine Sciences Group Black-Shale Composite or MSG:BSC) emphasizes the Paleozoic (Ordovician, Silurian, and Carboniferous) and middle Mesozoic (Jurassic), as most black shales were deposited then (Berry and Wilde, 1978). The MSG:BSC study includes samples (total 287, table 1) from the Cambrian (1), Lower Ordovician (90), Middle Ordovician (33), and Upper Ordovician (49), Lower Silurian (37), Carboniferous (19), and Jurassic (58). Samples were collected from continental Europe, Scandinavia, and North and South America. The samples were identified, stratigraphically and paleontologically, by W.B.N. Berry or were from well-documented collections (for example, Sedgwick Museum, Oxford, England; Museum of Paleontology, Berkeley, Calif.). The MSG:BSC study focused on field-identified black shales; nearly 90 percent of the samples contained less than 5 percent $\mathrm{CaCO}_{3}$. The study specifically excluded shaly limestone or limy shale containing greater than approximately 15 percent $\mathrm{CaCO}_{3}$ (Pettijohn, 1949, p. 291 ), in order to focus on the composition of the argillaceous black-shale facies.

\section{Analytical Procedures \\ Neutron Activation Analysis}

A suite of 41 elements was determined in the samples (table 2). All elemental abundances were determined at the Los Alamos National Laboratory using automated neutron activation analysis (Minor and others, 1982). Use of a single laboratory minimized the possibility of error commonly introduced by variations in analytical techniques or laboratories (Fairbairn and others, 1951; Quinby-Hunt and others, 1986). Most of the elemental concentrations were determined using conventional reduction of gamma-ray spectra of the radioactive isotopes.

Uranium was determined by delayed neutron counting. The automated system was calibrated using a collection of U.S. Geological Survey, U.S. National 
Table 1. Sample summary for Marine Studies Group Black-Shale Composite

[WBNB, W.B.N Berry; SMCU, Sedgwick Museum, Cambridge University, mainly from the Bulman collection; UCPMC, University of California, Paleontology Museum; LP, Lucien Platt, Bryn Mawr College, Bryn Mawr, Pa; RAR, Robert Raiswell, Leeds University, Leeds, England; PW, Pat Wilde, Marine Sciences Group, University of California, Berkeley; LUC, Lund University Collection; BCPC, Bolivian California Petroleum Company]

\begin{tabular}{|c|c|c|c|}
\hline Period & $\begin{array}{l}\text { Sample } \\
\text { Locality }\end{array}$ & $\begin{array}{c}\text { No. of } \\
\text { samples }\end{array}$ & Source \\
\hline \multicolumn{4}{|c|}{ MESOZOIC } \\
\hline \multirow[t]{2}{*}{ Jurassic... } & Oxfordian .... Switzerland....... & 6 & WBNB \\
\hline & Toarcian...... England .......... & 52 & WBNB \\
\hline \multicolumn{4}{|c|}{ PALEOZOIC } \\
\hline $\begin{array}{l}\text { Carbonif- } \\
\text { erous }\end{array}$ & Wesphalian... Wales............. & 9 & RAR \\
\hline \multirow[t]{6}{*}{ Silurian... } & Llandovery... Scotland .......... & 4 & WBNB \\
\hline & Llandovery... Scotland .......... & 3 & SMCU \\
\hline & Llandovery... Wales............. & 2 & WBNB \\
\hline & Llandovery... Norway ........... & 1 & WBNB \\
\hline & Llandovery... New Brunswick.. & 1 & WBNB \\
\hline & Llandovery... Maine............ & 1 & WBNB \\
\hline \multirow[t]{23}{*}{ Ordovician ... } & Ashgill........ Idaho ............ & 1 & WBNB \\
\hline & Ashgill........ Scotland .......... & 48 & WBNB \\
\hline & Ashgill........ Scotland .......... & 1 & SMCU \\
\hline & Late-Middle.. New York........ & 4 & WBNB \\
\hline & Late-Middle.. New Jersey....... & 7 & UCPMC \\
\hline & Middle........ Wales............. & 1 & WBNB \\
\hline & Middle........ Pennsylvania ..... & 6 & LP \\
\hline & Middle........ Pennsylvania ..... & 5 & UCPMC \\
\hline & Middle........ Norway ........... & 3 & WBNB \\
\hline & Middle........ New York........ & 4 & PW \\
\hline & Middle........ New Jersey........ & 1 & WBNB \\
\hline & Middle........ Maine............ & 1 & WBNB \\
\hline & Early-Middle. Newfoundland ... & 1 & SMCU \\
\hline & Tremadoc .... Norway ............ & 23 & WBMB \\
\hline & Tremadoc .... Sweden ........... & 21 & LUC \\
\hline & Tremadoc .... Quebec............ & 15 & WBNB \\
\hline & Tremadoc .... Wales............. & 14 & WBNB \\
\hline & Tremadoc .... Bolivia ............ & 6 & BCPC \\
\hline & Tremadoc .... New York........ & 4 & WBNB \\
\hline & Tremadoc .... Estonia ........... & 2 & SMCU \\
\hline & Tremadoc .... Belgium .......... & 2 & SMCU \\
\hline & Tremadoc .... New Brunswick.. & 2 & SMCU \\
\hline & Tremadoc .... Denmark ......... & 1 & SMCU \\
\hline Cambrian.... & Late-Middle. . Norway ........... & 1 & WBNB \\
\hline
\end{tabular}

Bureau of Standards, and Canadian Geological Survey standard rocks. The system was checked periodically for stability against these standards.

\section{Statistical Methods}

Frequency distributions for each element were plotted against the midpoints of distribution bins used in determining the distribution (fig. 1). Means and modes of elements in the MSG:BSC study are listed in table 2 with mean concentrations of Turekian and Wedepohl (1961) and Gromet and others (1984) for shales and means and modes of the V\&T:BSC study. In determining the mode and to facilitate comparison with the study of black shales by Vine and Tourtelot (1970, p. 257), we used their geometric concentration ranges. Each bin (fig. 1) has boundaries of 1.2, 1.8, 2.6, 3.8, 5.6, 8.3, 12, $18 \mathrm{ppm}$, and so on. For example, the midpoint of the bin containing data ranging from 0.83 to $1.2 \mathrm{ppm}$ is 1 ; the midpoint for the bin containing data from $1.2-1.8 \mathrm{ppm}$ is $1.5 \mathrm{ppm}$. The next consecutive midpoints are $2,3,5,7,10 \mathrm{ppm}$, and so on. The mode, as the midpoint in the frequencydistribution bin, is presented because the mean is sensitive to a few extreme values and may not indicate the central tendency in a distribution.

If less than 60 percent of the samples did not contain detectable levels of an element, we have presented the mean of the detectable concentrations; for the mode, we have listed the percentage of all samples containing less than the detectable concentration. For example, 134 ( 47 percent) of the 287 samples contained measurable amounts of calcium. The average calcium concentration for samples in which it was detected (fig. 1) was $17,000 \mathrm{ppm}$. However, the average sample containing undetectable quantities of calcium contained less than $800 \mathrm{ppm}$. In fact, 60 percent of all samples contained less than $2,600 \mathrm{ppm}$. Thus, the mode is given as " 60 percent $<2,600 \mathrm{ppm}$ " in table 2 .

\section{Discussion}

The low-calcic shales analyzed for this study showed less variability of composition for the unimodal elements than was observed by Vine and Tourtelot (1970) because, in this study, the samples were basically clays and other detrital minerals having little carbonate to complicate the mineralogy. The multimodality seen in these low-calcic shale samples suggests that factors affecting composition of black shales, other than source composition, are present during deposition and diagenesis.

This study demonstrates that the black-shale facies is chemically complex and contains several chemofacies. Ideally, if the black-shale facies observed in the field was a single chemical-sedimentary quantity, the elements characteristic of that facies would show a unimodal distribution. When compared with the classic shale composites (Turekian and Wedepohl, 1961; Gromet and others, 1984; Taylor and McLennan, 1985) and with the 
Table 2. Element concentrations in the Marine Sciences Group Black-Shale Composite compared to other shale and black-shale composites

[Concentrations in parts per million. NR, not reportred; <, less than; ( ), percent of samples containing less than the modal value of the eler

\begin{tabular}{|c|c|c|c|c|c|c|c|c|c|c|}
\hline \multicolumn{11}{|c|}{ Nonrare-earth elements } \\
\hline \multirow{3}{*}{ Element } & \multicolumn{5}{|c|}{ Marine Sciences Group Black-Shale Composite } & \multirow{2}{*}{\multicolumn{2}{|c|}{$\begin{array}{c}\text { Black shale } \\
1\end{array}$}} & \multicolumn{3}{|c|}{ Shale } \\
\hline & \multirow[b]{2}{*}{ Mean } & \multirow{2}{*}{ Mode* } & \multirow[b]{2}{*}{ Mi nimum } & \multirow[b]{2}{*}{ Maximum } & \multirow{2}{*}{$\begin{array}{l}\text { No. of } \\
\text { samples }\end{array}$} & & & 2 & 3 & 4 \\
\hline & & & & & & Mean & Mode* & Mean & Mean & Mean \\
\hline $\begin{array}{l}\mathrm{Na} \\
\mathrm{Mg} \\
\mathrm{Al} \\
\mathrm{Cl}\end{array}$ & $\begin{array}{r}5,260 \\
10,400 \\
82,100 \\
240^{+}\end{array}$ & $\begin{array}{r}7,000 \\
10,000 \\
70,000 \\
<120 \quad(75)\end{array}$ & $\begin{array}{r}380 \\
2,490 \\
14,700 \\
30\end{array}$ & $\begin{array}{r}24,800 \\
40,200 \\
129,900 \\
1,780\end{array}$ & $\begin{array}{r}287 \\
284 \\
287 \\
99\end{array}$ & $\begin{array}{r}7,000 \\
7,000 \\
70,000 \\
\text { NR }\end{array}$ & $\begin{array}{r}10,000 \\
7,000 \\
70,000 \\
\text { NR }\end{array}$ & $\begin{array}{r}9,600 \\
15,000 \\
80,000 \\
\text { NR }\end{array}$ & $\begin{array}{r}8,900 \\
13,000 \\
100,000 \\
\text { NR }\end{array}$ & $\begin{array}{r}7,500 \\
17,000 \\
89,000 \\
\text { NR }\end{array}$ \\
\hline $\begin{array}{l}K \\
C a \\
\text { Sc } \\
\text { Ti }\end{array}$ & $\begin{array}{c}29,900 \\
17,100^{+} \\
15.6 \\
4,340\end{array}$ & $\begin{array}{l}20,000 \\
<2,600(60) \\
15 \\
5,000\end{array}$ & $\begin{array}{c}3,500 \\
740 \\
1.5 \\
850\end{array}$ & $\begin{array}{c}83,600 \\
73,300 \\
30.7 \\
7,360\end{array}$ & $\begin{array}{l}286 \\
134 \\
287 \\
286\end{array}$ & $\begin{array}{r}20,000 \\
15,000 \\
10 \\
2,000\end{array}$ & $\begin{array}{r}30,000 \\
10,000 \\
10 \\
2,000\end{array}$ & $\begin{array}{r}26,600 \\
22,100 \\
13 \\
4,600\end{array}$ & $\begin{array}{r}31,000 \\
9,300 \\
16 \\
6,000\end{array}$ & $\begin{array}{c}32,000 \\
25,000 \\
14.9 \\
4,200\end{array}$ \\
\hline $\begin{array}{l}V \\
\mathrm{Cr} \\
\mathrm{Mn} \\
\mathrm{Fe}\end{array}$ & $\begin{array}{r}500 \\
111 \\
383 \\
36,800\end{array}$ & $\begin{array}{r}150 \\
100 \\
200 \\
50,000\end{array}$ & $\begin{array}{r}39 \\
10 \\
15 \\
2,500\end{array}$ & $\begin{array}{r}6,260 \\
418 \\
3,780 \\
99,800\end{array}$ & $\begin{array}{l}187 \\
278 \\
287 \\
287\end{array}$ & $\begin{array}{r}150 \\
100 \\
150 \\
20,000\end{array}$ & $\begin{array}{r}150 \\
70 \\
100 \\
30,000\end{array}$ & $\begin{array}{r}130 \\
90 \\
850 \\
47,200\end{array}$ & $\begin{array}{r}150 \\
110 \\
850 \\
50,000\end{array}$ & $\begin{array}{c}\text { NR } \\
124.5 \\
465 \\
40,000\end{array}$ \\
\hline $\begin{array}{l}\text { Co } \\
\mathrm{Zn} \\
\text { Ga } \\
\text { As }\end{array}$ & $\begin{array}{c}16.9 \\
310^{+} \\
21.9^{+} \\
28.8\end{array}$ & $\begin{array}{rr}20 & \\
<38 & (65) \\
<38 & (80) \\
20 & \end{array}$ & $\begin{array}{l}0.4 \\
7 \\
7.8 \\
1.3\end{array}$ & $\begin{array}{r}108 \\
3,800 \\
43.2 \\
152.6\end{array}$ & $\begin{array}{l}287 \\
106 \\
119 \\
279\end{array}$ & $\begin{array}{r}10 \\
<300 \\
20 \\
\text { NR }\end{array}$ & $\begin{array}{l}15 \\
t \dagger \\
20 \\
\text { NR }\end{array}$ & $\begin{array}{l}19 \\
95 \\
19 \\
\text { NR }\end{array}$ & $\begin{array}{l}23 \\
85 \\
20 \\
\text { NR }\end{array}$ & $\begin{array}{l}25.7 \\
\text { NR } \\
\text { NR } \\
28.4\end{array}$ \\
\hline $\begin{array}{l}\mathrm{Se} \\
\mathrm{Br} \\
\mathrm{RD} \\
\mathrm{Sr}\end{array}$ & $\begin{array}{l}5.6^{+} \\
4.0^{+} \\
131 \\
310^{+}\end{array}$ & $\begin{aligned}<5.6(80) \\
<2.6(76) \\
150 \\
<260(75)\end{aligned}$ & $\begin{array}{r}1.0 \\
0.9 \\
18 \\
150\end{array}$ & $\begin{array}{l}29.8 \\
36.1 \\
322 \\
530\end{array}$ & $\begin{array}{r}76 \\
106 \\
287 \\
21\end{array}$ & $\begin{array}{r}N R \\
N R \\
N R \\
200\end{array}$ & $\begin{array}{l}N R \\
N R \\
N R \\
200\end{array}$ & $\begin{array}{r}\mathrm{NR} \\
\mathrm{NR} \\
\mathrm{NR} \\
300\end{array}$ & $\begin{array}{c}\text { NR } \\
\text { NR } \\
160 \\
200\end{array}$ & $\begin{array}{l}\text { NR } \\
0.69 \\
125 \\
142\end{array}$ \\
\hline $\begin{array}{l}\text { Zr } \\
\text { Mo } \\
\text { In } \\
\text { SD }\end{array}$ & $\begin{array}{l}230^{+} \\
65^{+} \\
0.21^{+} \\
5.7\end{array}$ & $\begin{aligned}<380(90) \\
<18(65) \\
<0.18(76) \\
1.5\end{aligned}$ & $\begin{array}{l}39 \\
0.1 \\
0.08 \\
0.2\end{array}$ & $\begin{array}{c}1,010 \\
600 \\
0.60 \\
70.6\end{array}$ & $\begin{array}{r}99 \\
118 \\
66 \\
260\end{array}$ & $\begin{array}{l}70 \\
10 \\
\text { NR } \\
\text { NR }\end{array}$ & $\begin{array}{r}100 \\
+\dagger \\
N R \\
N R\end{array}$ & $\begin{array}{l}160 \\
2.6 \\
N R \\
N R\end{array}$ & $\begin{array}{l}210 \\
1.0 \\
N R \\
N R\end{array}$ & $\begin{array}{l}200 \\
\text { NR } \\
\text { NR } \\
2.09\end{array}$ \\
\hline $\begin{array}{l}\text { Cs } \\
\text { Ba } \\
\text { Hf } \\
\text { Ta }\end{array}$ & $\begin{array}{r}8.6 \\
1,120 \\
4.3 \\
0.9\end{array}$ & $\begin{array}{c}10 \\
300 \\
5 \\
0.7\end{array}$ & $\begin{array}{c}0.5 \\
140 \\
0.8 \\
0.3\end{array}$ & $\begin{array}{r}19.6 \\
50,200 \\
18.4 \\
1.8\end{array}$ & $\begin{array}{l}287 \\
279 \\
287 \\
275\end{array}$ & $\begin{array}{r}N R \\
300 \\
N R \\
N R\end{array}$ & $\begin{array}{r}N R \\
300 \\
N R \\
N R\end{array}$ & $\begin{array}{r}\text { NR } \\
139 \\
\text { NR } \\
\text { NR }\end{array}$ & $\begin{array}{c}15 \\
650 \\
5.0 \\
N R\end{array}$ & $\begin{array}{c}5.16 \\
636 \\
6.3 \\
1.12\end{array}$ \\
\hline $\begin{array}{l}W \\
\text { Au } \\
\text { Th } \\
\text { U }\end{array}$ & $\begin{array}{l}3.3^{+} \\
0.023 \\
11.6 \\
15.2\end{array}$ & $\begin{array}{c}<3.8 \quad(82) \\
\star \star \\
10 \\
3\end{array}$ & $\begin{array}{l}1.0 \\
0.007 \\
1.1 \\
1.2\end{array}$ & $\begin{array}{c}12.5 \\
0.052 \\
32.3 \\
442.6\end{array}$ & $\begin{array}{r}61 \\
14 \\
287 \\
287\end{array}$ & $\begin{array}{l}\text { NR } \\
N R \\
N R \\
N R\end{array}$ & $\begin{array}{l}\text { NR } \\
\text { NR } \\
\text { NR } \\
\text { NR }\end{array}$ & $\begin{array}{l}\text { NR } \\
\text { NR } \\
\text { NR } \\
\text { NR } \\
\end{array}$ & $\begin{array}{c}2.7 \\
N R \\
14.6 \\
3.1 \\
\end{array}$ & $\begin{array}{l}2.1 \\
N R \\
12.3 \\
2.66 \\
\end{array}$ \\
\hline
\end{tabular}

study of black shales by Vine and Tourtelot (1970), this study shows excellent agreement for the elements generally associated with detrital minerals, such as aluminum, titanium, and scandium. The trimodality of manganese concentrations indicates the possibility of three redox zones in black shales. Multimodality in volatile elements such as arsenic and antimony suggests that, additionally, a volcanic source may have an important chemical impact on the black-shale facies. The mean concentrations of elements of the organic and volatility indicators, vanadium, zinc, bromine, strontium, molybdenum, antimony, barium, and uranium, are significantly higher than the means for the shale composites and the Vine and Tourtelot (1970) compilation. This difference is due to the inclusion of the Dictyonema-bearing black shales of Balto-Scandia in our composite. Several authors have noted that certain black shales are enriched in various metals (Goldschmidt, 1954; Wedepohl, 1964; Vine and Tourtelot, 1970; Tardy, 1975; Holland, 1979; Berry and others, 1986). The exclusion of these black shales from alternative compilations biases projections of the global oceanic conditions in the Paleozoic and Mesozoic. We prefer to include these samples, noting both the mean and the strong multimodal character of their frequency distributions. This approach identifies elements typifying an average black shale but also identifies elements with multiple modes that show that black shales can form under two or more chemical environments. 
Table 2. Element concentrations in the Marine Sciences Group Black-Shale Composite compared to other shale and black-shale composites-Continued

[Concentrations in parts per million. NR, not reported; <, less than; ( ), percent of samples containing less than the modal value of the element]

\begin{tabular}{|c|c|c|c|c|c|c|c|c|c|c|c|}
\hline \multicolumn{12}{|c|}{ Rare-earth elements } \\
\hline \multirow{3}{*}{ Element } & \multicolumn{4}{|c|}{ Marine Sciences Group Black-Shale } & \multirow{3}{*}{ 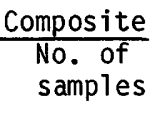 } & \multirow{2}{*}{\multicolumn{2}{|c|}{$\begin{array}{c}\text { Black shale } \\
1\end{array}$}} & \multicolumn{4}{|c|}{ Shale } \\
\hline & \multirow[b]{2}{*}{ Mean } & \multirow{2}{*}{ Mode ${ }^{*}$} & \multirow[b]{2}{*}{ Minimum } & \multirow[b]{2}{*}{ Maximum } & & & & 5 & 3 & 4 & 6 \\
\hline & & & & & & Mean & Mode* & Mean & Mean & Mean & Mean \\
\hline $\begin{array}{l}\mathrm{La} \\
\mathrm{Ce} \\
\mathrm{Nd} \\
\mathrm{Sm} \\
\mathrm{Eu}\end{array}$ & $\begin{array}{c}44 \\
80 \\
55 \\
6.2 \\
1.27\end{array}$ & $\begin{array}{c}50 \\
100 \\
50 \\
7 \\
1.5\end{array}$ & $\begin{array}{l}10 \\
13 \\
14 \\
0.8 \\
0.21\end{array}$ & $\begin{array}{l}111 \\
197 \\
130 \\
27.5 \\
5.26\end{array}$ & $\begin{array}{l}286 \\
282 \\
214 \\
280 \\
285\end{array}$ & $\begin{array}{l}30 \\
\text { NR } \\
\text { NR } \\
\text { NR } \\
\text { NR }\end{array}$ & $\begin{array}{l}30 \\
\text { NR } \\
\text { NR } \\
\text { NR } \\
\text { NR }\end{array}$ & $\begin{array}{l}0.30 \\
0.84 \\
0.58 \\
0.21 \\
0.074\end{array}$ & $\begin{array}{l}38 \\
80 \\
32 \\
5.6 \\
1.1\end{array}$ & $\begin{array}{l}31.1 \\
66.7 \\
27.4 \\
5.59 \\
1.18\end{array}$ & $\begin{array}{c}41.1 \\
81.3 \\
40.1 \\
7.3 \\
1.52\end{array}$ \\
\hline $\begin{array}{l}\text { TD } \\
\text { Dy } \\
\text { YD } \\
\text { Lu }\end{array}$ & $\begin{array}{l}0.95 \\
4.85 \\
3.10 \\
0.47\end{array}$ & $\begin{array}{l}1 \\
5 \\
3 \\
0.5\end{array}$ & $\begin{array}{l}0.06 \\
0.25 \\
1.29 \\
0.07\end{array}$ & $\begin{array}{r}2.42 \\
10.73 \\
6.21 \\
0.90\end{array}$ & $\begin{array}{l}265 \\
285 \\
286 \\
270\end{array}$ & $\begin{array}{l}\text { NR } \\
\text { NR } \\
\text { NR } \\
\text { NR }\end{array}$ & $\begin{array}{l}\text { NR } \\
\text { NR } \\
\text { NR } \\
\text { NR }\end{array}$ & $\begin{array}{l}0.049 \\
0.31 \\
0.17 \\
0.031\end{array}$ & $\begin{array}{l}0.77 \\
4.4 \\
2.8 \\
0.43\end{array}$ & $\begin{array}{l}0.85 \\
\text { NR } \\
3.06 \\
0.456\end{array}$ & $\begin{array}{l}1.05 \\
\text { NR } \\
3.29 \\
0.58\end{array}$ \\
\hline
\end{tabular}

${ }^{*}$ The mode is the midpoint of distribution bins used for detemining the frequency distribution by the method of Vine and Tourtelot (1970) (see text). If less than 60 percent of the samples contained detectable amounts of the element, the frequency distribution of the detection limit was examined in conjunction with the detectable concentrations and the percentage of samples below a certain concentration determined.

\footnotetext{
+These values are means of the samples in which less than 60 percent of the samples contained detectable concentrations.

ttFor these elements Vine and Tourtelot (1970) indicated a majority of samples less than the lower limit of detection using spectrography.

**Too few values available for calculation of meaningful mode.
}

\section{SOURCES OF SAMPLES}

1. Black-shale composite (V\&T:BSC), Vine and Tourtelot (1970).

2. Shale, Turekian and Wedepohl (1961).

3. Post-Archean Australian shales, Taylor and McLennan (1985).

4. North American Shale Composite, Gromet and others (1984).
5. Chondrite, Haskin and others (1966).

6. European shales, Haskin and Haskin (1966).

\section{Conclusions}

Black shales, which seem to be an easily identifiable and distinct sedimentary facies, represent a complex chemical system that contains several chemofacies and includes a wide range of redox conditions. The variability of composition observed in this study of lowcalcic black shales shows the need to examine distributional modes other than the mean when characterizing chemofacies associated with depositional environments. Comparisons with other composites, with respect to redox sensitive elements, indicate that the black-shale facies have a wider range of redox conditions than seen in published general composites. As such composites (for example, the North American shale composite) are used for normalization of chemical data, their usefulness as a standard, particularly for investigations of nonoxic shales, must be questioned. On the other hand, a well-documented black-shale composite may be a more valid standard for paleo- oceanographic and comparative chemical studies, especially in Paleozoic and earlier times when the redox conditions in the oceans were not as uniform or as oxic as in the modern oceans.

\section{References}

Berry, W.B.N., and Wilde, Pat, 1978, Progressive ventilation of the oceans-an explanation for the distribution of the Lower Paleozoic black shales: Americal Journal of Science, v. 278, p. 257-275.

Berry, W.B.N., Wilde, Pat, Quinby-Hunt, M.S., and Orth, C.J., 1986, Trace element signatures in Dictyonema shales and their geochemical and stratigraphic significance: Norsk Geologisk Tidsskrift, v. 66, p. 45-51.

Fairbairn, H.W., and others, 1951, A cooperative investigation of precision and accuracy in chemical, spectrochemical and modal analysis of silicate rocks, in Contributions to geochemistry, 1950-51: U.S. Geological Survey Bulletin 980, p. 1-71.

Goldschmidt, V. M., 1954, Geochemistry: Oxford, England, Oxford University Press, $730 \mathrm{p}$. 

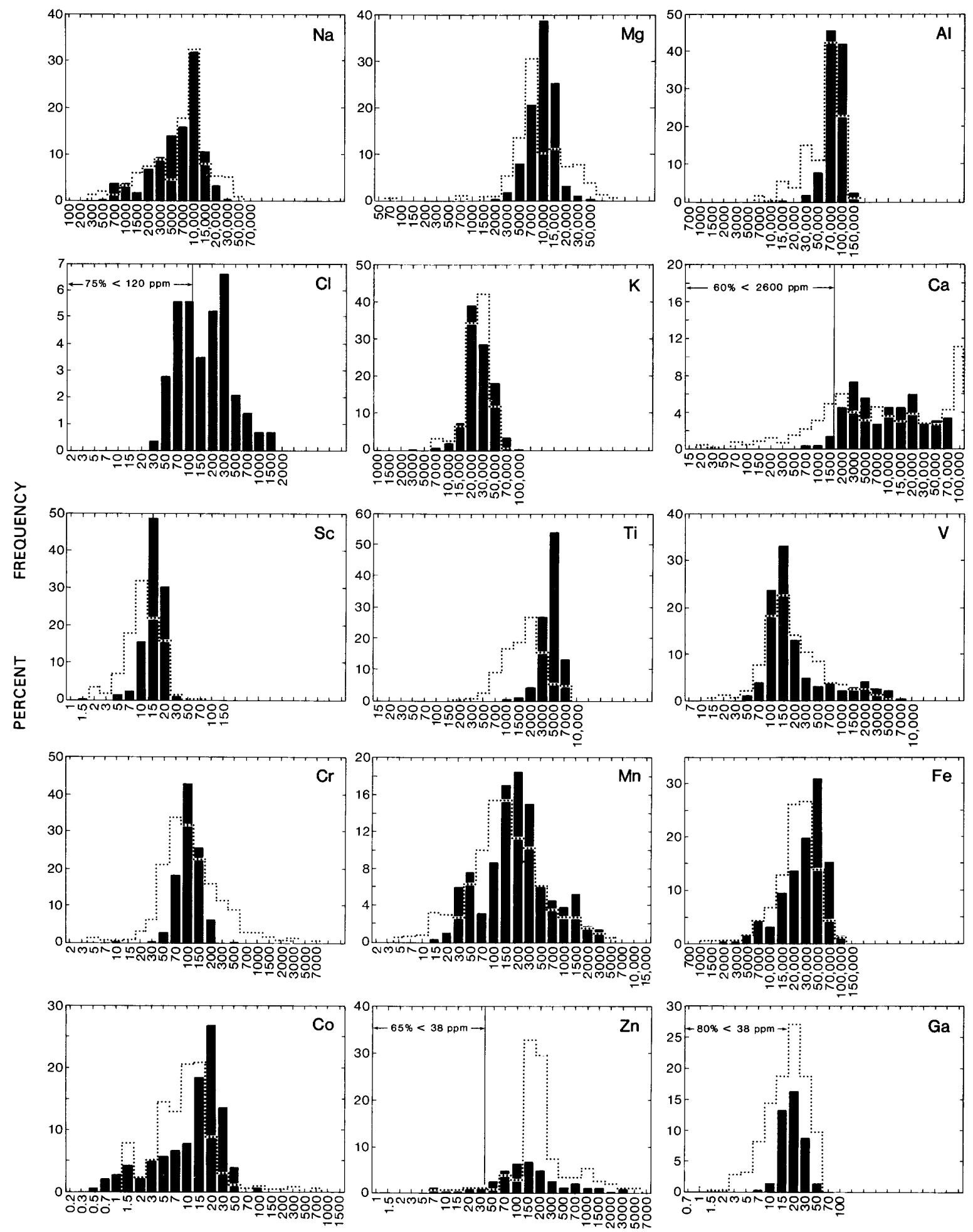

ABUNDANCE IN PPM

Figure 1 (above and following pages). Frequency distributions of the concentrations of the elements in the low-calcic shales of the Marine Studies Group Black-Shale Composite. Bar graph represents the percentage of samples falling within a given frequency range. Dotted lines show the frequency distribution of Vine and Tourtelot (1970). The graph gives the midpoint of each concentration range. See text for further explanation of concentration ranges and frequency distributions. 

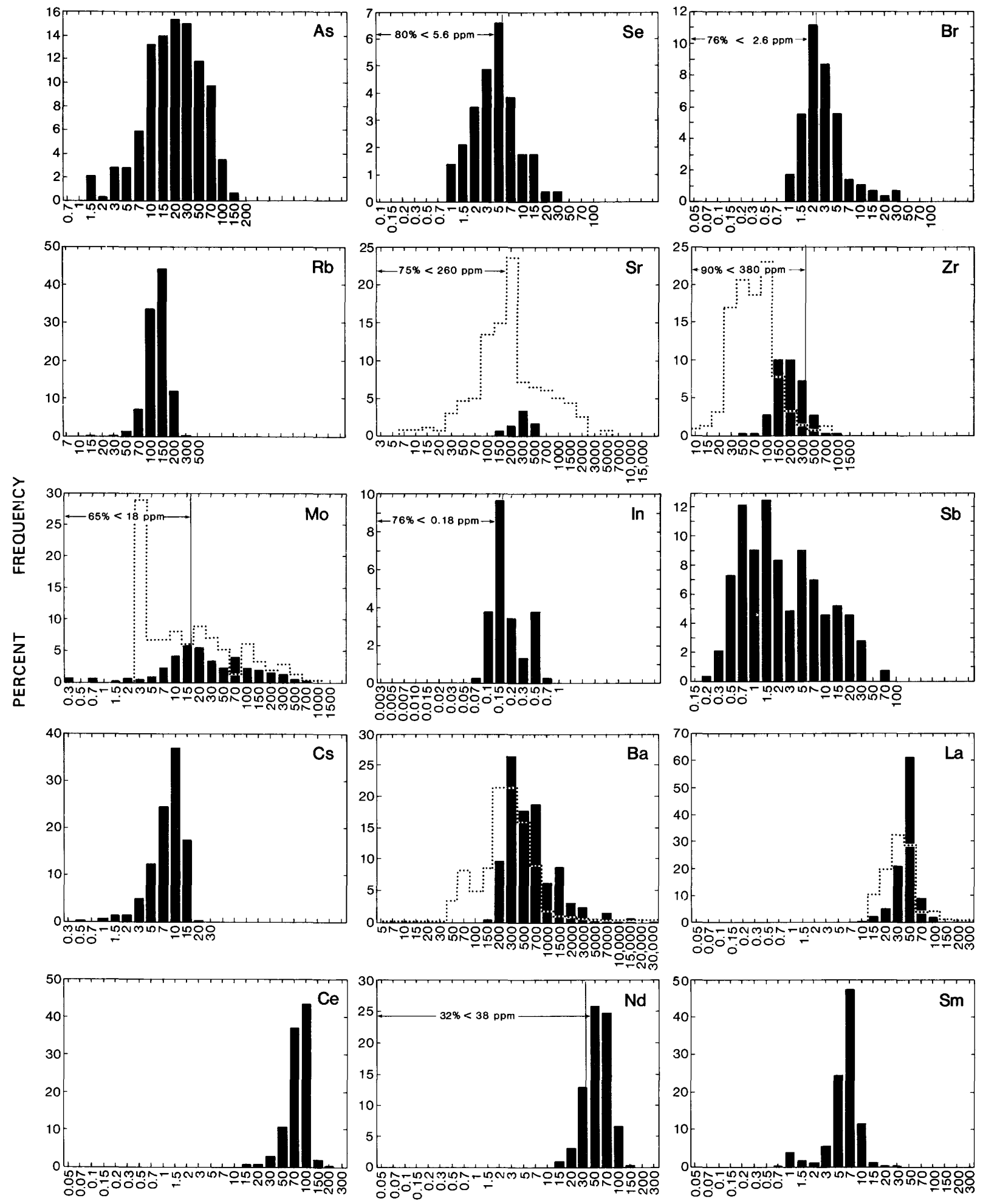

Gromet, L.P., Dymek, R.F., Haskin, L.A. and Korotev, R.L., 1984, The "North American shale composite"-Its compilation, major and trace element characteristics: Geochimica et Cosmochimica Acta, v. 48, p. 2469-2482.
Haskin, L.A., Frey, F.A., Schmitt, R.A., and Smith, R.H., 1966, Meteoritic, solar and terrestrial rare-earth distributions, in Physics and chemistry of the Earth, Volume 7: New York, Pergamon Press, p. 167-321. 

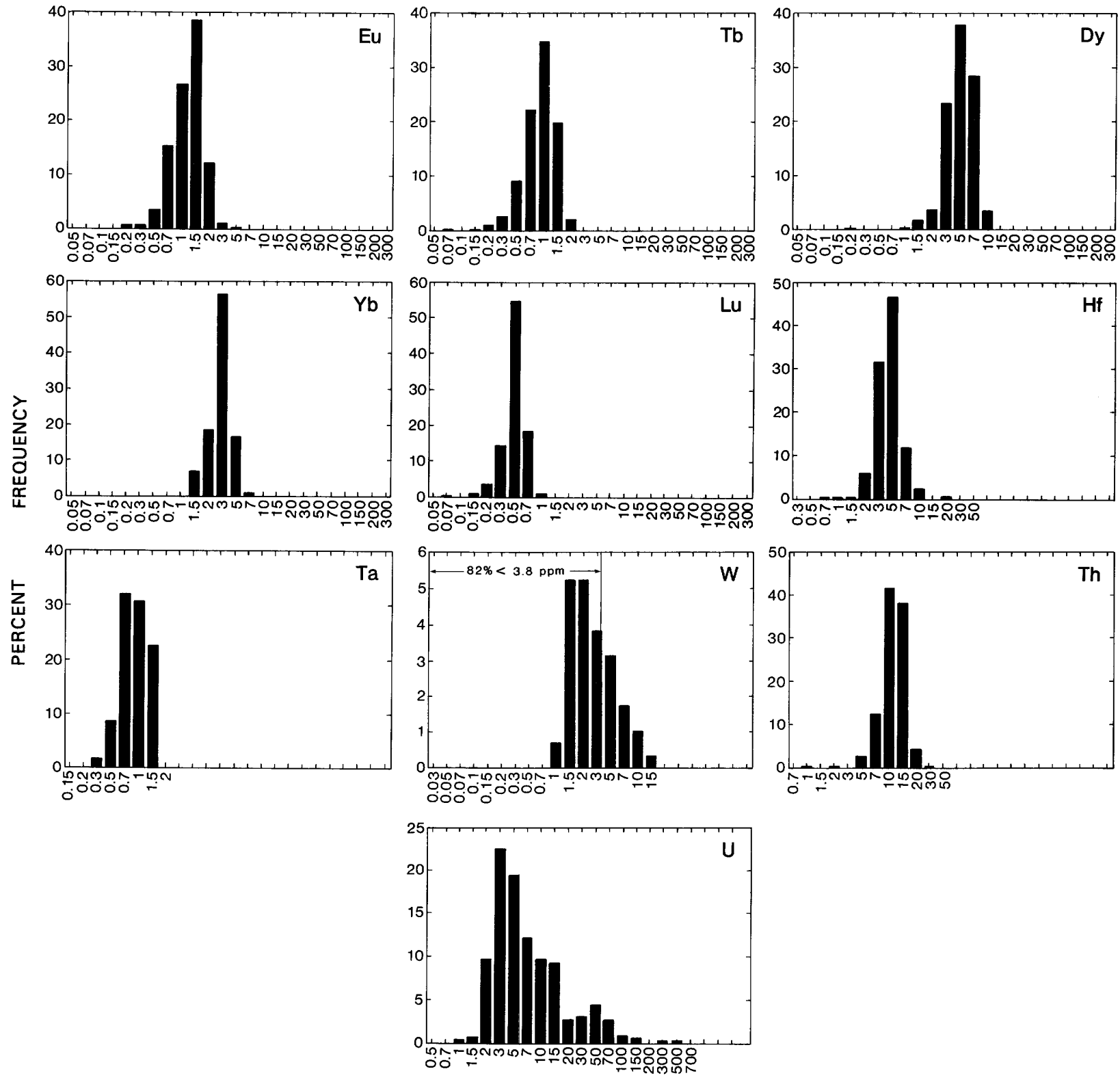

ABUNDANCE IN PPM

Haskin, M.A., and Haskin, L.A., 1966, Rare earths in European shales-A redetermination: Science, v. 154, p. 507-509.

Holland, H.D., 1979, Metals in black shales-A reassessment: Economic Geology, v. 74, p. 1676-1680.

Minor, M.M., Hensley, W.K., Denton, M.M., and Garica, S.R., 1982, An automated activation analysis system: Journal of Radioanalytical Chemistry, v. 70, p. 459-471.

Pettijohn, F. J., 1949, Sedimentary rocks: New York, Harper and Brothers, $526 \mathrm{p}$.

Quinby-Hunt, M.S., McLaughlin, R.D., and Quintanilha, A.T., 1986, Instrumentation for environmental monitoring, Volume 2, in Greenberg, A.E., and Morton, G.A., eds., Water (2nd ed.): New York, Wiley, 982 p.
Tardy, Yves, 1975, Element partition ratios in some sedimentary environments, I. Statistical treatments, II. Studies on North American black shales: Strasbourg Sciences Géologiques Bulletin, v. 28, p. 59-95.

Taylor, S.R., and McLennen, S.M., 1985, The continental crust-Its composition and evolution: Oxford, England, Blackwell Scientific Publication, 312 p.

Turekian, K.K., and Wedepohl, K.H., 1961, Distribution of the elements in some major units of the Earth's crust: Geological Society of America Bulletin, v. 72, p. 175-191.

Vine, J.D., and Tourtelot, E.B., 1970, Geochemistry of black shale deposits--A summary report: Economic Geology, v. 65 , p. 253-272. 
Wedepohl, K.H., 1964, Untersuchen am Kupferschiefer in Nordwestdeutschland; Ein Beitrag zur Deutung der Genese bituminoser Sedimente: Geochimica et Cosmochimica Acta, v. 28, p. 305-364.

Wedepohl, K.H., 1968, Chemical fractionation in the sedimentary environment, in Ahrens, L.H., ed., Origin and distribution of the elements: Oxford, England, Pergamon Press, p. 999-1016.

\section{Sulfide-Mineral Textures in Metal-Rich Units of the New Albany Shale, Indiana}

\author{
By E.M. Ripley, Department of Geology, Indiana \\ University, Bloomington, IN 47405, and N.R. \\ Shaffer, Indiana Geological Survey, \\ Bloomington, IN 47405
}

Sulfide minerals occur in various textural forms in heavy-metal-enriched units of the New Albany Shale (Middle and Late Devonian and Early Mississippian) of Indiana. Most heavy-metal-enriched beds are characterized by high organic-carbon contents (as much as 25 weight percent). Sulfur content varies typically from 1 to 6 weight percent. Base-metal contents may be very elevated; some occur as sulfides.

Early sulfide-mineral assemblages consist of pyrite, chalcopyrite, sphalerite, galena, and rarely pyrrhotite or an iron-nickel sulfide. Pyrite occurs as framboids (either solid or disjointed), single crystals, spore fillings, and, in places, colloform aggregates. Chalcopyrite occurs as individual grains, as rims around or intergrown with sphalerite, or with pyrrhotite in cores of grains enclosed by sphalerite. Sphalerite is also found as euhedral to anhedral individual grains, as rims around pyrite framboids, as interstitial filling of pyrite framboids, or as distinct spherical to elongate grains enclosed by organic material. Galena, with as much as 5 percent selenium, is found rarely in association with sphalerite. Later stage sulfides are mainly pyrite fracture or syneresis fillings.

Textural features of sphalerite occurrences indicate formation syngenetically or during early diagenesis, but mechanisms of precipitation varied within local microenvironments. Replacement of the interior part of spores or semifusinite grains and crystallization in intergrain sites apparently devoid of organic matter or pyrite has occurred. The localization of sphalerite around clusters of pyrite framboids (without replacement of pyrite) may indicate differences in morphological response during coprecipitation or a later replacement of organic material that initially enclosed pyrite. Textural features suggest that sphalerite developed in an euxinic $\left(\mathrm{H}_{2} \mathrm{~S}\right.$-bearing) water column or pore system. Although communication with seawater was probably restricted, sufficient zinc and other metals were present in seawater, organic debris, or detrital materials to promote local deposition of sulfides in select $\mathrm{H}_{2} \mathrm{~S}$-rich environments.
Geochemical and Mineralogic Data Indicating Possible Stratabound, Bariferous Base- and Precious-Metal Deposits in the Black Slates of the Taconic Ranges, New York and Vermont, U.S.A.

\author{
By Kenneth C. Watts, Jr., U.S. Geological \\ Survey, MS 973, Box 25046, Denver Federal \\ Center, Denver, CO 80225
}

A regional geochemical survey of drainage-basin sediments in the Taconic Ranges of New York and Vermont has identified areas in which the bedrock contains significant amounts of lead, zinc, copper, cobalt, molybdenum, barium, arsenic, and silver, and probably tin and antimony. The high concentrations of these elements and the rock-forming elements iron, manganese, calcium, and strontium, identify regions favorable for the occurrence of stratabound base-metal deposits. The nonmagnetic heavy-mineral suite was the chief source of data from the drainage-basin sediment samples. Sieved stream-sediment samples provided significant data on the distribution of zinc and arsenic.

The base-metal anomalies are from pyrite, arsenopyrite, rare chalcopyrite, and weathered limonitic debris (some of which may be after sphalerite). Tin, antimony, and lead anomalies are associated with unidentified oxides. Their remote (progenitor) source is most likely a sulfosalt mineral. Barium anomalies occur in barite and bariferous carbonate.

The general trends of the base-metal anomalies, as interpreted from isopleth maps of metal abundances, suggest that the element sources are specific rock units in the Taconic sequence which could contain stratabound metal deposits. A geochemical survey of rocks, following the stream-sediment survey, confirmed that some rock units are highly enriched in barium, arsenic, copper, molybdenum, zinc, silver, phosphorus, iron, and manganese. High metal contents were found in black slates (commonly near a black slate-green slate interface) and in associated carbonate units. These rocks are considered to be the source of the metal anomalies in drainage-basin sediment samples. Certain carbonate breccias, for example, are highly enriched in zinc, barium, molybdenum, and arsenic. The black slates are most highly enriched in molybdenum and barium. Most barium contents range from 500 to $3,000 \mathrm{ppm}$, but rare samples exceed 1 percent. Phosphatic units occur throughout the Taconic sequence but seem to have higher phosphorus contents close to sulfide-rich units.

The regional stream-sediment data is from 171 drainage-basin samples. Computer-generated isopleth maps of metal abundances were prepared from the data, 
and R-mode factor analyses were made in which the factor score results were plotted on isopleth maps. About 67 percent of the data variance can be explained by the following factors, in order of amount of variance accounted for:

Factor 1: V, Nb, Mg, Ti, Mn, B, Cu.

Factor 2: $\mathrm{Fe}, \mathrm{Co}, \mathrm{As}, \mathrm{Zn}, \mathrm{Cu}$.

Factor 3: $\mathrm{Ca}, \mathrm{Sr}, \mathrm{Ba}, \mathrm{Pb}$.

Factor 4: $\mathrm{La}, \mathrm{Cr}, \mathrm{B}, \mathrm{Sc}$.

Factor 5: $\mathrm{Bi}, \mathrm{Ag}, \mathrm{Pb}$, As.

Factor 6: $\mathrm{Be}, \mathrm{Au}, \mathrm{Sn}$.

Factor 7: Sn, Mo, Sb, Cu.

Factor 1 is a detrital mineral association that indicates rutile, mafic sheet silicates, and tourmaline. Factor 2 is a sulfide association, primarily related to the distribution of pyrite and arsenopyrite in the black slates and carbonates. Factor 3 is related to the carbonate lithologies. These associations suggest that barium and lead are more closely associated with carbonate-rich units than with low-carbonate black slate. The associated elements calcium and strontium clearly indicate a carbonate component. Factor 4 is related to the detrital mineral fraction of the black slates. Factor 5 is considered a sulfosalt association, probably from stratabound sources. The map distribution of factor 5 suggests but does not prove that they originated in the sedimentary sequence and not in cross-cutting veins. Factor 6 is likely related to rift-related mineralization of Mesozoic age. Factor 6 metals were probably derived from cross-cutting, post-tectonic veins, on the basis of sporadic isopleth map patterns. Factor 7 is another probable sulfosalt association whose source is yet to be identified.

These field, geochemical, and statistical studies show the importance and potential of the black slate and carbonate units of the Taconic Ranges for mineral deposits. Much work is yet to be done. 


\section{MEMBERSHIP OF THE U.S. WORKING GROUP OF \\ INTERNATIONAL GEOLOGICAL CORRELATION PROGRAM PROJECT 254 \\ METALLIFEROUS BLACK SHALES AND RELATED ORE DEPOSITS}

Roger Ames

AMOCO

P.O. Box 3385

Tulsa, OK 74101

Belinda Arbogast

U.S. Geological Survey

MS 973, Box 25046, Denver Federal Center

Denver, CO 80225

Michael A. Arthur ${ }^{1}$

Graduate School of Oceanography

University of Rhode Island

Narragansett Bay Campus

Narragansett, RI 02882-1197

Lance S. Barron

Kentucky Energy Cabinet Laboratory

P.O. Box 13015

Iron Works Pike

Lexington, KY 40512-3015

Joy Beier

Biogeochemical Laboratories

Indiana University

Bloomington, IN 47401

Pieter Berendsen ${ }^{1}$

Kansas Geological Survey

University of Kansas, Campus West

Lawrence, KS 66045

Merwin Berstein

Berstein Y Thomson Ltda.

Casilla 13806

Santiago, Chile

William B.N. Berry ${ }^{1}$

Marine Sciences Group

Department of Paleontology

University of California, Berkeley

Berkeley, CA 94720

Edward Bloomstein ${ }^{1}$

Santa Fe Pacific Mining Corporation 6200 Uptown Blvd. NE, Suite 400

Box 27019

Albuquerque, NM 87125-7019
George N. Breit ${ }^{1}$

U.S. Geological Survey

MS 913, Box 25046, Denver Federal Center

Denver, CO 80225

William F. Cannon

U.S. Geological Survey

MS 954, National Center

Reston, VA 22092

Chen-Lin Chou

Illinois State Geological Survey

Natural Resources Building

615 East Peabody Drive

Champaign, IL 61820

Sandra H. B. Clark ${ }^{1}$

U.S. Geological Survey

MS 954, National Center

Reston, VA 22092

Raymond M. Coveney, Jr. ${ }^{1}$

Department of Geosciences

University of Missouri-Kansas City

Kansas City, MO 64110-2499

Jeremy Dahl $^{1}$

Department of Earth Sciences

University of California at Los Angeles

Los Angeles, CA 90024

Walter E. Dean, Jr. ${ }^{1}$

U.S. Geological Survey

MS 916, Box 25046, Denver Federal Center

Denver, CO 80225

George A. Desborough

U.S. Geological Survey

MS 905, Box 25046, Denver Federal Center

Denver, CO 80225

Albert B. Dickas

Grants and Special Programs

University of Wisconsin-Superior

Superior, WI 54880 
Eric R. Force

U.S. Geological Survey

2255 North Gemini Drive

Flagstaff, AZ 86001

Robert M. Garrels

Department of Marine Sciences

University of South Florida

St. Petersburg, FL 33701

(Deceased, 1988)

Robert N. Ginsburg

University of Miami

Fisher Island

Miami Beach, FL 33139

Martin B. Goldhaber

U.S. Geological Survey

MS 973, Box 25046, Denver Federal Center

Denver, Colorado 80225

Pamela Gore

Department of Geology

Emory University

Atlanta, GA 30322

Richard I. Grauch ${ }^{1}$

U.S. Geological Survey

MS 973, Box 25046, Denver Federal Center

Denver, CO 80225

Richard Hagni

Department of Geology

University of Missouri-Rolla

Rolla, MO 65401

Dick Hammond ${ }^{1}$

South Dakota Geological Survey

University of South Dakota Science Center

Vermillion, SD 57069

P.E. Hare

Geophysical Laboratory

2801 Upton Street NW

Washington, DC 20008

Joseph R. Hatch ${ }^{1}$

U.S. Geological Survey

MS 977, Box 25046, Denver Federal Center

Denver, CO 80225

Eileen S. $\mathrm{Ho}^{1}$

Department of Geological Sciences

University of Michigan

Ann Arbor, MI 48109-1063
Holly L. O. Huyck ${ }^{1}$

Department of Geology

University of Cincinnati

Mail Location 13

Cincinnati, OH 45221

E. Craig Jowett

Department of Earth Sciences

University of Waterloo

Waterloo, Ontario, Canada N2L 3G1

Richard M. Kettler ${ }^{1}$

Department of Geological Sciences

University of Michigan

Ann Arbor, MI 48109-1063

Mike Lambert

Kansas Geological Survey

1930 Constant Avenue, Campus West

University of Kansas

Lawrence, KA 66046

Joel S. Leventhal ${ }^{1}$

U.S. Geological Survey

MS 973, Box 25046, Denver Federal Center

Denver, CO 80225

Timothy W. Lyons ${ }^{1}$

Department of Geology and Geophysics

Yale University

P.O. Box 6666

New Haven, CT 06511

J. Barry Maynard

Department of Geology

University of Cincinnati

Cincinnati, OH 45221-0013

Phillip A. Meyers ${ }^{1}$

Department of Atmospheric and Oceanic Sciences

University of Michigan

Ann Arbor, MI 48109

James Murowchick ${ }^{1}$

Department of Geosciences

University of Missouri-Kansas City

Kansas City, MO 64110-2499

Bartholomew S. Nagy ${ }^{1}$

Department of Geosciences

University of Arizona

520 Gould-Simpson Building

Tucson, AZ 85721 
Suzanne O'Connell

Ocean Drilling Program

Texas A\&M University Research Park

1000 Discovery Drive

College Station, TX 77840

Patrick M. Okita ${ }^{1}$

U.S. Geological Survey

MS 954, National Center

Reston, VA 22092

Robert H. Parker

Coastal Eco Systems Management, Inc.

120 N. Rupert Street

Fort Worth, TX 76107

F. G. Poole ${ }^{1}$

U.S. Geological Survey

MS 905, Box 25046, Denver Federal Center

Denver, CO 80225

Mary S. Quinby-Hunt ${ }^{1}$

Marine Sciences Group

Department of Paleontology

University of California, Berkeley

Berkeley, CA 94720

Thomas L. Robl

Kentucky Energy Cabinet Laboratory

P.O. Box 13015

Iron Works Pike

Lexington, KY 40512-3015

Robert B. Sanders

Sanders Resource Associates, Inc. 11661 Rockridge Drive

Anchorage, AK 99516

Jeanine Schmidt ${ }^{1}$

U.S. Geological Survey

4200 University Drive

Anchorage, Alaska 99508

Nelson R. Shaffer ${ }^{1}$

Indiana Geological Survey

611 North Walnut Grove

Bloomington, IN 47401
Patricia Sheahan

Konsult International Inc.

44 Gemini Road

Willowdale, Ontario, Canada M2K 2G6

Kevin Shelton

Department of Geology

University of Missouri-Columbia

Columbia, MO 65211

D. A. Spears

Department of Geology

University of Sheffield

Mappin Street

Sheffield, England S1 3JD

Nur Iskandar Taib

Department of Geology

Indiana University

Bloomington, IN 47405

Franklyn B. Van Houten

Department of Geological and Geophysical Sciences

Princeton University

Guyot Hal

Princeton, NJ 08544

James D. Vine ${ }^{1}$

21736 Panorama Drive

Golden, CO 80401

Kenneth C. Watts ${ }^{1}$

U.S. Geological Survey

MS 973, Box 25046, Denver Federal Center

Denver, CO 80225

Pat Wilde

Marine Sciences Group

Department of Paleontology

University of California, Berkeley

Berkeley, CA 94720

Sherwood W. Wise, Jr.

Departments of Geology and Oceanography

Florida State University

Tallahassee, FL 32306

\footnotetext{
${ }^{1}$ Attended United States Working Group Meeting, Denver, Colorado, October, 1988.
} 


\section{AUTHOR INDEX}

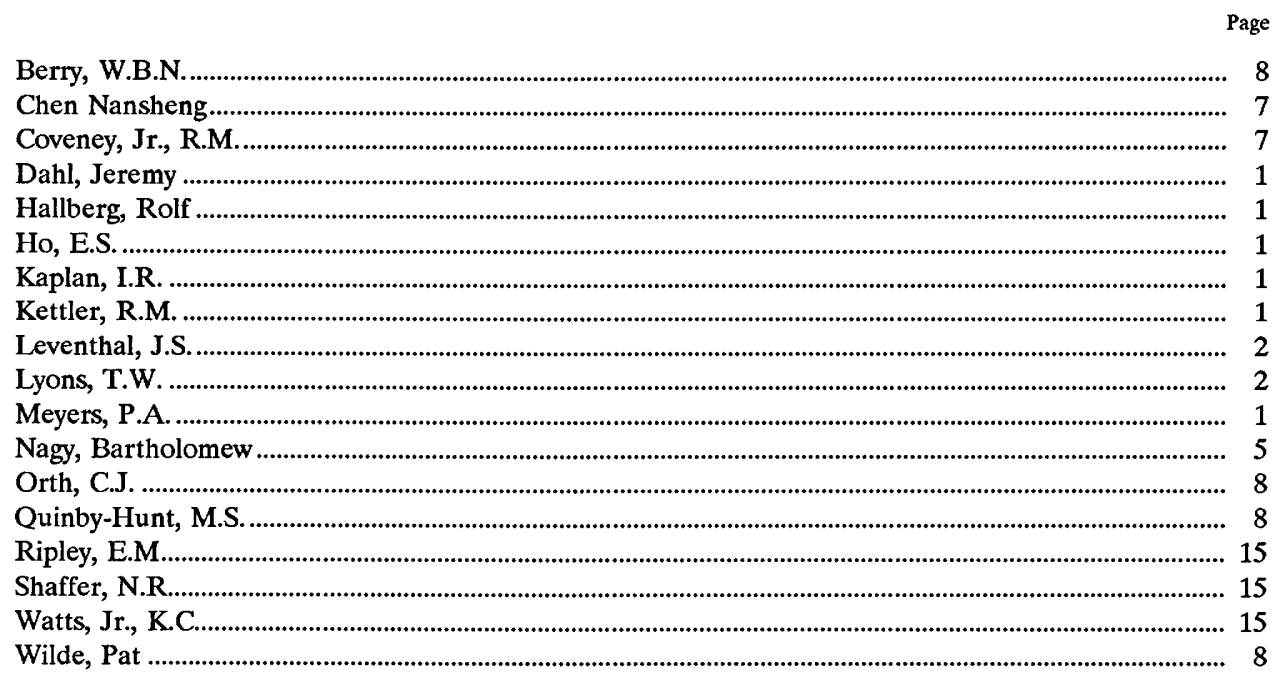

